\title{
Review
}

\section{Mechanisms of Connexin Mimetic Peptides}

\author{
D. Ryan King ${ }^{1}$, Meghan W. Sedovy 1,2, Xinyan Leng ${ }^{1}$, Jianxiang Xue ${ }^{3}$, Samy Lamouille ${ }^{1,4}$, Michael Koval 5, Brant E.
}

Isakson ${ }^{3,6}$, Scott R. Johnstone ${ }^{1,4,7 *}$

1 Fralin Biomedical Research Institute at Virginia Tech Carilion School of Medicine, Virginia Tech, Roanoke VA 24016; ryanking@vt.edu (D.R.K.); msedovy@vt.edu (M.W.S.); xleng@vt.edu (X.L.); lamouils@vt.edu (S.L.); scottrj@vt.edu (S.R.J.)

2 Translational Biology, Medicine, and Health Graduate Program, Virginia Tech, Blacksburg VA 24061; msedovy@vt.edu (M.W.S.)

3 Robert M. Berne Cardiovascular Research Center, University of Virginia School of Medicine, Charlottesville VA 22908; uxm8hs@virginia.edu (J.X.); brant@virginia.edu (B.E.I.)

4 Center for Vascular and Heart Research, Virginia Tech, Roanoke VA 24016; lamouils@vt.edu (S.L.); scottrj@vt.edu (S.R.J.)

5 Department of Medicine, Division of Pulmonary, Allergy, Critical Care and Sleep Medicine, and Department of Cell Biology, Emory University School of Medicine, Atlanta, GA 30322; mhkoval@emory.edu (M.K.)

6 Department of Molecular Physiology and Biophysics, University of Virginia School of Medicine, Charlottesville VA 22908; brant@virginia.edu (B.E.I.)

7 Department of Biological Sciences, Virginia Tech, Blacksburg VA 24060; scottrj@vt.edu (S.R.J.)

* Correspondence: scottrj@vt.edu

\begin{abstract}
Gap junctions (GJ) and connexins play integral roles in cellular physiology and have been found to be involved in multiple pathophysiological states from cancer to cardiovascular disease. Studies over the last 60 years have demonstrated the utility of altering GJ signaling pathways in experimental models, which has led to them being attractive targets for therapeutic intervention. A number of different mechanisms have been proposed to regulate GJ signaling, including channel blocking, enhancing channel open state, and disrupting protein-protein interactions. The primary mechanism for this has been through the design of numerous peptides as therapeutics, that are either currently in early development or are in various stages of clinical trials. Despite over 25 years of research into connexin targeting peptides, the overall mechanisms of action are still poorly understood. In this overview, we discuss published connexin targeting peptides, their reported mechanisms of action and the potential for these molecules in the treatment of disease.
\end{abstract}

Keywords: connexin, gap junction, hemichannel, pannexin, peptide, cell signaling

\section{Introduction}

1.1 Gap junctions, hemichannels, and connexin proteins as therapeutic targets

Gap junction channels (GJ) were first identified in the 1960s[1-3] and have since been reported to control numerous physiologic and pathophysiologic functions. GJs are composed of connexin (Cx) proteins, of which 21 isoforms have been identified[4]. All known connexin isoforms are structurally similar, being composed of 4 transmembrane domains, 2 extracellular loops (EL1, EL2) bound in conformation by extracellular disulfide bonds, a single intracellular loop (IL), an amino-terminus (NT), and a carboxyl-terminus (CT)[4,5]. Variations among connexin isoforms are primarily found within the length and amino acid sequence of the IL and CT domains. Connexin proteins hexamerize to form single 
membrane channels called hemichannels (also known as connexons) in either the endoplasmic reticulum or the golgi apparatus, depending on isoform, prior to trafficking to the plasma membrane[6]. Once at the membrane, hemichannels may dock with compatible hemichannels on the membrane of neighboring cells, forming GJs that permit direct intercellular cell-to-cell signaling.

GJs are non-selectively permeable to molecules up to $\sim 1 \mathrm{kDa}$ and are not considered to be highly charge selective, although charge may play a role in altering rates of transfer of molecules across the pore due to steric hindrance[5,7-10]. Hemichannels have been shown to function independent of GJ formation, facilitating the release of molecules such as ATP, ADP, and glutamate[11-13]. While hemichannel signaling has been canonically studied at the plasma membrane, recent evidence suggests that hemichannel signaling is also present at the mitochondrial membranes[14-16]. Connexin proteins, independent of channel formation (GJ or hemichannel), have also been shown to act directly as signaling molecules, forming protein-protein interactions that regulate cellular fate[17-22]. Further, internal translation of the Cx43 protein leads to the formation of short connexin isoforms (20-30 kDa, e.g. GJA1-20k) that function within the cell to facilitate protein trafficking to the plasma membrane, mitochondrial membranes, and nuclear compartment[23-28].

GJs and connexins are dynamically regulated through protein post-translational modifications of the IL, NT, and CT[29-36]. The intracellular CT domain of most connexin proteins consists of a largely unstructured stretch of amino acids that tend to be rich in modifiable residues that can undergo nitrosylation (cysteine), phosphorylation (serine/ threonine/ tyrosine) and SUMOylation (lysine) as well as other modifications via acetylation, hydroxylation, and carboxylation (Figure 1)[30,37-42]. Post-translational modifications may lead to conformational changes in extracellular domains to inhibit channel docking and limit GJ formation, in pore forming sites to alter channel permeability, and in signaling and intracellular domains that affect protein trafficking, membrane stability, and protein-protein interactions.

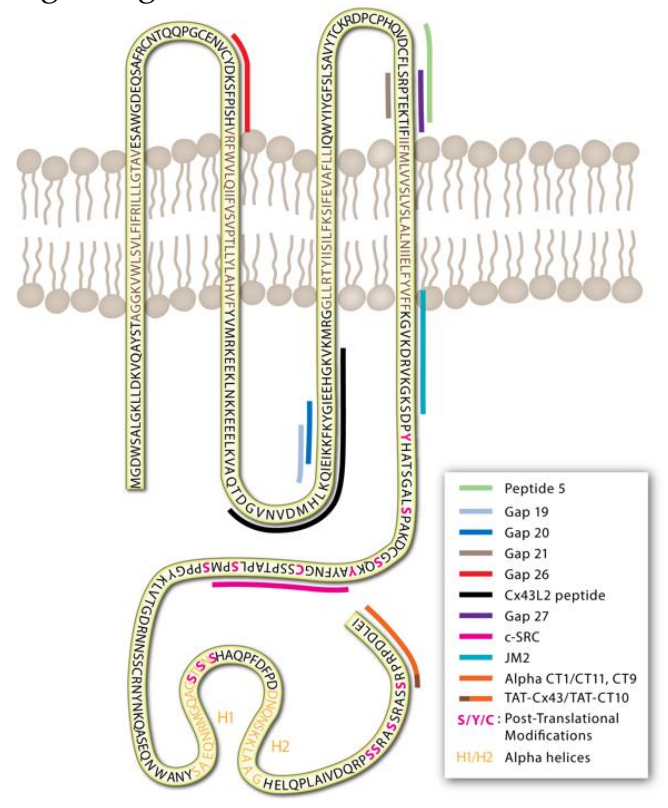

Figure 1: Schematic of the Cx43 protien in the plasma membrane with colored lines indicating the positions of described peptides targeting EL, IL and CT regions.

Connexin isoform expression and function is variable throughout the body. Dysfunctional GJs are often associated with diseases such as cancer, cardiovascular disease, wound and tissue remodeling, and sensoneurial defects[5,31,4347]. As such, GJs and connexin proteins are attractive therapeutic targets. While there are presently no therapeutics directly targeting connexin proteins or GJs that are approved for clinical use, several have been investigated in clinical trials[48-50]. The primary focus for intervention has been peptides that have indirect and direct effects on the connexin channels and protein functions. There have been many excellent reviews on connexin therapeutics and peptides developed over the last 25 years[51-56]. In this review, we focus specifically on GJ and connexin peptides that have been developed and aim to discuss the potential mechanisms through which they function. This is an area of much debate and there has been a recent push towards understanding the peptide-protein structural relationship. 


\section{Indirect acting peptides that alter GJs and connexins}

Cx43 has long been identified as a major cardiac connexin, regulating conduction between cardiomyocytes and playing critical roles in normal heart function through GJ and hemichannel signaling[57]. Reduced Cx43 expression, altered membrane localization, and changes in connexin phosphorylation states have all been observed during ischemic heart disease and are associated with the development of cardiac arrythmias[58-60]. In 1980, a naturally occurring antiarrhythmic peptide, labelled AAP10, was identified in bovine serum[55,61]. Given the links between Cx43 dysregulation and arrythmia development, studies of the AAP10 peptide and its derivatives (Table 1) have centered around their effects in promoting GJ function and subsequent maintenance of cardiac rhythmic conduction[48,62].

Since the identification of AAP10, more stable forms of anti-arrhythmic peptides have been manufactured[55]. From the original AAP10 molecule, modifications by sequence inversion and replacement by D-amino acids led to the production of ZP123 (rotagaptide), a more stable peptide analogue[55]. Multiple pre-clinical trials in rat, rabbit, pig, and canine models found AAP10 and rotagaptide to preserve cardiac conduction, increase GJ signaling, and limit ischemia induced cardiac damage and arrhythmia development[48,62-65]. Further modifications of the AAP10 led to the production of danegaptide (also referred to as ZP1609 and GAP-134), which showed a similar degree of reduction in post-ischemic infarct size in pig and canine models[66,67]. Despite the promising pre-clinical data for AAP10, rotagaptide, and danegaptide, none of these peptides were found efficacious in Phase II clinical trials[49,55]. The exact reason for a lack of efficacy is not clear, but has been speculated elsewhere[55,68].

Despite their failure to decrease phenotypic disease burden, AAP10, rotagaptide, and danegaptide do alter the pattern of Cx43 expression, phosphorylation, GJ signaling, and hemichannel signaling[17,69-71]. Studies have demonstrated that these peptides increase both Cx43 and Cx40 GJ signaling[69,72]. Unlike the peptides to be discussed later in this review, the AAP10 derivative peptides do not contain sequence homology with connexin proteins. AAP10, rotagaptide, and danegaptide are not presumed to be membrane permeable. Rather, the peptides are suspected to bind with a membrane bound G-protein coupled receptor (GPCR), although the precise receptor remains unknown[73,74]. It is hypothesized that peptide binding with a GPCR leads to the activation of protein kinase C (PKC) pathways, which in turn modify Cx43 and Cx40 functions[69,73]. Prolonged treatment with AAP10 and rotagaptide has been shown to increase $\mathrm{Cx} 43$ protein synthesis, expression, and membrane retention in cultured HeLa cells, primary rat ventricular cardiomyocytes, and dermal fibroblasts[17,69,75,76].

Phosphorylation is a key event in the lifecycle of most connexin proteins. For instance, in Cx43, de-phosphorylation of Cx43-S282 or phosphorylation at Cx43-S373 is linked to a reduction in GJ signaling following ischemia[58,77]. Conversely, phosphorylation at sites such as PKC-associated Cx43-S262 and Cx43-S368 are reportedly protective against ischemia reperfusion injury $[77,78]$. In ischemic hearts, temporal reductions in site specific Cx43 phosphorylation are associated with asystole, which is alleviated through treatment with AAP10 in rabbits and by rotagaptide in rats $[62,65]$. Both AAP10 and rotagaptide promote PKC activation, inducing Cx43-S368 phosphorylation and subsequent opening of Cx43 GJs[62,69,75,79-81]. Mass spectrometry analysis of cardiomyocytes also demonstrate that phosphorylation at S297 and S368 is lost subsequent to ischemia in untreated hearts, yet preserved by treatment with rotagaptide[55,65,82].

Studies in cultured endothelial cells suggest that danegaptide preserves Cx43 GJ signaling and reduces apoptosis under high glucose conditions[83]. In astrocytes, danegaptide treatments increase GJ and hemichannel signaling and produce protective effects such as reduced infarct volume following a stroke in mice[84]. In aged mice, danegaptide induces similar effects to AAP10 and rotagaptide, increasing Cx43-S368 phosphorylation, preserving Cx43 expression with the overall effect of reducing cardiac fibrosis[71]. In addition to membrane associated GJ functions, these peptides were proposed to stabilize $\mathrm{Cx} 43$, which could limit the generation of damaging reactive oxygen species associated with mitochondrial Cx43. However, in murine cardiac cell preparations, danegaptide was found to exert its effects independent of mitochondrial $\mathrm{Cx} 43$, suggesting it may have other molecular targets and pathways outside of Cx43[16,66,85].

The AAP10 peptide has also been proposed to enhance cancer therapeutic treatments[86], stem cell differentiation[87], and may increase homocysteine-induced cardiomyocyte cell apoptosis[88]. However, the exact 
pathways through which this occurs remain to be fully investigated and more insight is required into how the antiarrhythmic peptides function by binding GPCRs resulting in therapeutic protection.

Table 1: Connexin Peptides

\begin{tabular}{|c|c|c|c|c|c|c|c|c|}
\hline \multirow[t]{2}{*}{ Year } & \multirow[t]{2}{*}{ Peptide } & \multirow[t]{2}{*}{ Sequence/ Formula } & \multicolumn{2}{|c|}{ Known Target Cx } & \multirow[t]{2}{*}{ Linker } & \multirow[t]{2}{*}{ Properties } & \multirow{2}{*}{$\begin{array}{c}\text { Increase } \\
\text { Cx43- } \\
\text { PKC }\end{array}$} & \multirow[t]{2}{*}{ Ref. } \\
\hline & & & $\mathrm{Cx}$ & Region & & & & \\
\hline \multicolumn{9}{|c|}{ Non-mimetic peptides - indirect effects } \\
\hline 1980 & AAP10 & $\begin{array}{l}\text { H-GAG-4hyp-PY- } \\
\text { CONH }\end{array}$ & $\begin{array}{l}\mathrm{C} \times 43^{*} \\
\mathrm{C} \times 40^{*}\end{array}$ & \multirow{3}{*}{$\begin{array}{l}\text { Indirect: } \\
\text { Unknow } \\
\text { n GPCR } \\
\text { pathway }\end{array}$} & - & \multirow{3}{*}{$\begin{array}{l}\text { Increases Cx synthesis, } \\
\text { expression, } \\
\text { phosphorylation, } \\
\text { membrane targeting } \\
\text { and GJ opening }\end{array}$} & $\mathrm{Y}$ & $\begin{array}{l}{[55,69,73,} \\
74,81]\end{array}$ \\
\hline 2003 & $\begin{array}{l}\text { Rotagaptide } \\
\text { (ZP123) }\end{array}$ & $\begin{array}{l}\text { H2N-GDAGD-4hyp- } \\
\text { DPDY-Ac }\end{array}$ & $\mathrm{C} \times 43^{*}$ & & $\begin{array}{l}\text { N-term } \\
\text { Acetyl }\end{array}$ & & $\mathrm{Y}$ & {$[48]$} \\
\hline 2013 & $\begin{array}{l}\text { Danegaptide } \\
\text { (ZP1609, } \\
\text { GAP134) }\end{array}$ & $\mathrm{C}_{14} \mathrm{H}_{17} \mathrm{~N}_{3} \mathrm{O}_{4}$ & $\mathrm{C} \times 43^{*}$ & & - & & $\mathrm{Y}$ & {$[66,71]$} \\
\hline \multicolumn{9}{|c|}{ Extracellular Loop1 (EL1) } \\
\hline 1997 & Gap26 & VCYDKSFPISHVR & $\begin{array}{l}\mathrm{C} \times 43 \\
\mathrm{C} \times 32, \mathrm{C} \times 26\end{array}$ & $64-76$ & - & HC block & $\mathrm{Y}$ & {$[89,90]$} \\
\hline 2001 & ${ }^{43}$ Gap26 & VCYDKSFPISHVR & $\mathrm{C} \times 43$ & $64-76$ & - & HC block & $\mathrm{Y}$ & {$[91,92]$} \\
\hline 2009 & ${ }^{43} \mathrm{Gap} 26 \mathrm{M}$ & VCYDKSFPISHVR & $\mathrm{Cx} 43$ & $64-76$ & $\begin{array}{l}\text { N-term } \\
\text { Acetyl }\end{array}$ & HC block & $\mathrm{Y}$ & {$[92,93]$} \\
\hline 2001 & ${ }^{37,40} \mathrm{Gap} 26$ & VCYDQAFPISHIR & $\mathrm{C} \times 37, \mathrm{C} \times 40$ & & - & HC block & ND & [91] \\
\hline 1999 & Unlabelled & ICNTLQPGCNSV & $\mathrm{C} \times 32$ & $52-63$ & - & GJ block & ND & {$[94]$} \\
\hline 2007 & Peptide 1848 & CNTQQPCCENVCY & $\mathrm{Cx} 43$ & $54-66$ & - & GJ Block & ND & [95] \\
\hline \multicolumn{9}{|c|}{ Extracelluar Loop 2 (EL2) } \\
\hline 1999 & Unlabelled & $\begin{array}{l}\text { SLSAVYTCKRDPCP } \\
\text { HE }\end{array}$ & $\mathrm{C} \times 43$ & 180-195 & - & GJ block & ND & [96] \\
\hline 1999 & Unlabelled & $\begin{array}{l}\text { FLDTLHVCRRSPCP } \\
\text { HP }\end{array}$ & $\mathrm{Cx} 40$ & $177-192$ & - & GJ block & ND & [96] \\
\hline 2001 & ${ }^{37,43}$ Gap27 & SRPTEKTIFII & $\begin{array}{l}\text { Cx43, Cx37, } \\
\text { Cx32, Cx26 }\end{array}$ & $201-211$ & - & HC block & $\mathrm{Y}$ & {$[89-92,97]$} \\
\hline 2001 & ${ }^{40} \mathrm{Gap} 27$ & SRPTEKNVFIV & $\mathrm{Cx} 40$ & $201-211$ & - & GJ block & ND & {$[90,91,97]$} \\
\hline 2011 & ${ }^{32} \mathrm{Gap} 27$ & SRPTEKTVFT & $\mathrm{C} \times 32$ & 182-191 & - & HC block & ND & [98] \\
\hline 2021 & ${ }^{62 \mathrm{Gap} 27}$ & SRPTEKTIFML & CX62 & $201-211$ & - & HC \& GJ block & ND & [99] \\
\hline 2008 & Peptide 5 & VDCFLSRPTEKT & EL2 & EL2 & $\begin{array}{l}\text { s- } \\
\text { lipidation }\end{array}$ & HC \& GJ block & ND & [100-103] \\
\hline 2013 & $\begin{array}{l}\text { SRPTEKT/ } \\
\text { GAP21 }\end{array}$ & SRPTEKT & $\begin{array}{l}\mathrm{C} \times 32 \\
\mathrm{C} \times 43\end{array}$ & $\begin{array}{l}182-188 \\
204-210\end{array}$ & - & HC block & ND & {$[89,98]$} \\
\hline 2018 & $\begin{array}{l}\text { SRPTEKT-Hdc } \\
\text { (Gap21) }\end{array}$ & SRPTEKT-Hdc & $\mathrm{C} \times 43$ & EL2 & $\begin{array}{l}\text { Hexadecyl } \\
(\mathrm{HC}) \text { lipid } \\
\text { moeity }\end{array}$ & HC \& GJ block & $\mathrm{Y}$ & {$[104,105]$} \\
\hline
\end{tabular}




\begin{tabular}{|c|c|c|c|c|c|c|c|c|}
\hline 2013 & $\begin{array}{l}\mathrm{C} 12-\mathrm{C} \times 43 \quad \mathrm{MP} \\
\text { and } \mathrm{C} 12-\mathrm{C} 12- \\
\mathrm{C} \times 43 \mathrm{MP}\end{array}$ & $\begin{array}{l}\text { C12- } \\
\text { VDCFLSRPTEKT } \\
\text { C12-C12- } \\
\text { VDCFLSRPTEKT }\end{array}$ & $\mathrm{C} \times 43$ & $199-210$ & $\begin{array}{l}1 / 2 \quad \mathrm{C} 12- \\
\text { Laa } \\
\text { moieties }\end{array}$ & HC block & ND & [106] \\
\hline \multicolumn{9}{|c|}{ Intracellular Loop (IL) } \\
\hline 2006 & $\begin{array}{l}{ }^{32} \mathrm{GAP} 24 \\
\text { TAT-GAP24 }\end{array}$ & $\begin{array}{l}\text { GHGDPLHLEEVKC } \\
\text { YGRKKRRQRRRGH } \\
\text { GDPLHLEEVKC }\end{array}$ & $\begin{array}{l}\text { Cx32 } \\
\text { Cx43 } \\
\text { Panx1 }\end{array}$ & $110-122$ & $+/-\mathrm{TAT}$ & $\begin{array}{l}\text { HC block } \\
\text { Inhibit GJ formation }\end{array}$ & ND & $\begin{array}{l}{[10,107,1} \\
08]\end{array}$ \\
\hline 2004 & L2 (Cx43L2) & $\begin{array}{l}\text { DGVNVEMHLKQIE } \\
\underline{\text { IKKFKYGIEEHGK }}\end{array}$ & Cx43 & $119-142$ & - & $\begin{array}{l}\text { HC block not GJ } \\
\text { GJ block }\end{array}$ & ND & $\begin{array}{l}{[39,109,1} \\
10]\end{array}$ \\
\hline 2010 & TAT-L2 & $\begin{array}{l}\text { TAT- } \\
\text { DGANVDMHLKQI } \\
\text { EIKKFKYGIEEHGK }\end{array}$ & $\mathrm{C} \times 43$ & $119-142$ & TAT & HC block & ND & [111] \\
\hline 2013 & Gap19 & KQIEIKKFK & Cx43 & $128-136$ & - & HC block & ND & $\begin{array}{l}{[108,112,} \\
113]\end{array}$ \\
\hline 2014 & TAT-Gap19 & KQIEIKKFK & Cx43 & $128-136$ & TAT & HC block & ND & [114] \\
\hline 2020 & Xentry-Gap19 & KQIEIKKFK & Cx43 & $128-136$ & LCLRPV & HC block & & [115] \\
\hline 2010 & TAT-Cx50L2 & $\begin{array}{l}\text { GGERAPLAADQGS } \\
\text { VKKSSSSSKGTKK }\end{array}$ & Cx50 & $122-147$ & TAT & $\begin{array}{l}\text { ND Cx50, } \\
\text { No effect on Cx43 HC }\end{array}$ & ND & [111] \\
\hline & Gap 20 & EIKKFKYGC & Cx43 & $131-138$ & - & No effect & ND & [116] \\
\hline & Gap 22 & AELSCNKEVNG & $\mathrm{C} \times 40$ & $130-140$ & - & No effect & ND & [89] \\
\hline \multicolumn{9}{|c|}{ N-terminus/ C-terminus } \\
\hline 2005 & Alpha CT1 & RPRPDDLEI & $\mathrm{C} \times 43$ & $374-382$ & $\begin{array}{l}\text { Antennap } \\
\text { edia }\end{array}$ & $\begin{array}{l}\text { Promotes GJ formation, } \\
\text { enhance GJ, } \\
\text { HC block }\end{array}$ & Y & [117-119] \\
\hline 2009 & $\begin{array}{l}\text { Alpha CT11 } \\
\text { aka (Alpha CT2) }\end{array}$ & RPRPDDLEI & Cx43 & $374-382$ & None & $\begin{array}{l}\text { Promotes GJ formation, } \\
\text { enhance GJ, } \\
\text { HC block }\end{array}$ & Y & {$[119,120]$} \\
\hline 2009 & Alpha CT3 & $\begin{array}{l}\text { RQPKIWFPNRRKP } \\
\text { WKKRPSSRASSRAS } \\
\text { SRPRPDDLEI }\end{array}$ & Cx43 & $359-382$ & $\begin{array}{l}\text { Antennap } \\
\text { edia }\end{array}$ & ND & ND & [119] \\
\hline 2010 & TAT-C $x 43 C T$ & SRPRPDDLEI & Cx43 & $373-382$ & TAT & $\begin{array}{l}\text { Maintains open } \\
\text { channel and permits } \\
\text { dye transfer. Inhibits } \\
\text { HC block }\end{array}$ & ND & [111] \\
\hline 2011 & CT9 & RPRPDDLEI & Cx43 & $374-382$ & +/- TAT & HC block & Y & $\begin{array}{l}{[98,121,1} \\
22]\end{array}$ \\
\hline 2013 & TAT-CT10 & SRPRPDDLEI & $\mathrm{C} \times 43$ & $373-382$ & TAT & $\begin{array}{l}\text { Inhibits the effect of } \\
\text { CxL2 peptdies - stops }\end{array}$ & ND & [112] \\
\hline
\end{tabular}




\begin{tabular}{|l|l|l|l|l|l|l|l|l|}
\hline & & & & & & $\begin{array}{l}\text { L2 hemichannel } \\
\text { blockade }\end{array}$ & \\
\hline 2010 & TAT-Cx50CT & SRARSDDLTV & Cx50 & $431-440$ & TAT & $\begin{array}{l}\text { ND - Cx50, } \\
\text { No effect on Cx43 HC }\end{array}$ & ND & [111] \\
\hline 2010 & ZP2519 & $\begin{array}{l}\text { AcRRK-(4 hydroxy } \\
\text { benzoyl) }\end{array}$ & $\begin{array}{l}\text { Cx43 C- } \\
\text { term }\end{array}$ & Cx43 & $231-245$ & Antennap & HC block & GJ opening \\
\hline 2015 & $\begin{array}{l}\text { Juxtamembrane } \\
2 \text { (JM2) }\end{array}$ & $\begin{array}{l}\text { VFFK- } \\
\text { GVKDRVKGRSD } \\
283\end{array}$ & $\begin{array}{l}\text { AYFNGCSSPTAPLS } \\
\text { PMSP }\end{array}$ & Cx43 & $266-283$ & TAT & ND & [124] \\
\hline
\end{tabular}

\section{Connexin-mimetic peptides}

Connexin-mimetic peptides differ from the AAP10 peptide derivatives in that they represent consensus amino acid sequence alignments for EL (1/2), IL, or CT regions of connexins (Figure 1). Connexin-mimetics initially were synthesized for use as epitopes for connexin antibody production[127,128]. The blocking antibodies raised using these peptides against the EL and IL domains of several connexins were tested as GJ blockers and demonstrated some effect in reducing dye transfer in chick embryos[113]. However, EL loop antibodies Gap7M (EL1/2), Gap11 (EL1/2 Cx32), Gap15 (IL of Cx43), and Gap17 (CT Cx40) were found to be ineffective in functional testing and were not able to reduce connexin-associated contractile responses in rabbit arterial tone[89]. Despite this, Dahl et al. described that peptides, used to generate antibodies, were effective in reducing Cx32 GJ formation and signaling in oocytes[129]. In 1995, Becker et al. found that connexin-mimetic peptides, mimicking the sequences of the IL domain, could effectively block GJ channels when directly injected into embryo cells[113]. In the subsequent decades, a number of connexin-mimetic peptides have been generated and tested with a multitude of proposed functions including blockade of hemichannel and GJ signaling, alterations in GJ formation, and disruption of protein localization and protein-protein interactions (Table 1). While a few pathways of action have been identified, many of these peptides still function through unknown mechanisms.

\subsection{Connexin-mimetic peptides that target the extracellular loops}

Connexin targeting peptides were initially designed with sequence homology to the EL regions of the protein, with the intent of direct peptide-protein binding and subsequent GJ channel blockade[51,89]. Exactly why the connexinmimetic peptides would bind in this way has not been well described, but it was assumed that they could act to inhibit normal protein interactions or docking functions of hemichannels to GJs, thus blocking hemichannel opening, GJ formation and/or GJ signalling[51,130,131].

The early peptides targeting the EL - Gap21, Gap26, Gap27 and "Peptide 5" (a peptide shifted by 5 amino acids towards the $\mathrm{N}^{\prime}$ end of Gap27) - were designed against EL1 and EL2 of Cx32 and Cx43 (Table 1)[89,132]. Peptides targeting the EL of Cx32 (Gap21) were shown to delay GJ formation and electrical synchronization in chick cardiomyocytes[132]. Gap26 and Gap27 peptides effectively reduce Cx43 GJ and hemichannel functions[133,134]. Peptide 5, described by O'Carroll et al.[100], is reported to block hemichannel functions with effects in neuroprotection following spinal cord injuries, vascular leak, and ischemia[101-103,135]. In rabbit arterial sections, Gap21, Gap26, and Gap27 reduce phenylephrine induced vasoconstriction[89].

Given the proposed consensus peptide-protein binding mechanism, it was presumed that the connexin-mimetics would be highly specific. For example, the Gap26 peptide sequence, VCYDKSFPISHVR, corresponds to amino acids 6476 of Cx43-EL1. However, this peptide also altered channel functions of Cx32, Cx37, and Cx40 in a wide range of tissues[51]. This appears to result from the highly conserved nature of connexin sequences in the EL regions[91,93,136]. For example, Gap26 has 100\% homology with human Cx43-EL (accession CAG46461), but also greater than 75\% similarity with Cx40-EL (accession NP_005257), Cx32-EL (accession NP_001091111) and Cx37-EL (accession number 
NP_002051.2). Studies by Warner et al. suggested that key peptide amino acid motifs $\underline{\text { SHRV }}$ and $\underline{\text { SRPTEK}}$ found in many connexin EL1 and EL2 loops, may play a dominant role in channel blockade[89,132]. It is possible then, that these sites are critical for peptide-protein binding, which potentially limits connexin specificity.

Peptides that are reportedly more specific, targeting Cx32, Cx37, Cx40 and Cx43, were later developed by adjusting the amino acid sequences within Gap26 and Gap27 to produce ${ }^{37,40} \mathrm{Gap} 26,{ }^{43} \mathrm{Gap} 26(\mathrm{M}),{ }^{32} \mathrm{Gap} 27$, ${ }^{40} \mathrm{Gap} 27$, and ${ }^{37,43} \mathrm{Gap} 27$ (Table1)[91]. Most recently, ${ }^{62} \mathrm{Gap} 27$ has also been designed and tested for the inhibition of Cx62 in platelets, with no reported cross talk with Cx40 and Cx37 hemichannels[99]. ${ }^{43}$ Gap26 and ${ }^{37,43}$ Gap27 have wide ranging effects reported in many tissues including. These include the inhibition of acetylcholine responses in smooth muscle cells, reduced dye transfer in cultured cells[137], accelerated migration and wound closure in fibroblasts, keratinocytes, and epithelial cells[43,138,139], and limited ischemic damage following injury in hearts[140]. The design of ${ }^{40}$ Gap27, only differs from the ${ }^{37,43}$ Gap27 by three amino acids and still contains the SRPTEK motif[90,91,97,141]. Several studies suggest that ${ }^{40}$ Gap27 is specific to Cx40 GJs but not Cx43 or Cx37[90,97,137]. ${ }^{40}$ Gap27 does not inhibit dye transfer in COS-7 fibroblasts that express Cx43 and not Cx40, demonstrating that the ${ }^{40} \mathrm{Gap} 27$ peptide does not regulate Cx43[90,97]. Addition of lipid alkyl groups (C12-Laa) increased peptide stability of a short region of the GAP27 peptide by around 2 fold[106]. This was further adapted by incorporating a hexadecyl lipid moiety (C16 lipid, hexadecyl-NH2; Hdc) at the CT of "Peptide 5" and GAP27 peptides to produce SRPTEKT-Hdc[105,142]. SRPTEKT-Hdc is reported to block hemichannels and GJs, as measured by inhibition of hemichannel dye uptake (opening) and reduced $\mathrm{Ca}^{2+}$ wave propagation[105,142].

Gap26 and Gap27 peptides, and their iterations, have been shown to increase intracellular $\mathrm{Ca}^{2+}$ concentrations, similar to observations following treatments with the non-selective GJ blocker glycyrrhetinic acid in cultured endothelial cells and smooth muscle cells[97,98]. The peptides desynchronized $\mathrm{Ca}^{2+}$ transients in cultured cells and in rat mesenteric arteries associated with reductions in vasomotion[98,143]. In cultured endothelial cells and smooth muscle cells, ${ }^{37,40} \mathrm{Gap} 26$ and ${ }^{40} \mathrm{Gap} 27$ inhibited GJ based dye transfer, but did not alter synthesis or de novo formation of GJ plaques at concentrations up to $600 \mu \mathrm{M}$ [97]. However, later studies suggested that this may be cell type specific, as Gap27 decreases transcription and protein expression of Cx43 in juvenile dermal fibroblasts[43].

Both Gap 26 and Gap27 peptides induce PKC phosphorylation of Cx43-S368, associated with reduced GJ signaling[92,105,144,145]. The EL2 peptide SRPTEKT-hdc (containing the same Cx sequence as Gap21[89]) blocked GJ function, which is also related to increased PKC-associated Cx43-S368 phosphorylation[105,142]. Treatments with ${ }^{62} \mathrm{Gap} 27$ also activates protein kinase A (PKA) pathways in platelets, although it is not currently clear if this has a direct effect on the Cx62 protein phosphorylation[99].

It is still not clear how the EL-targeting peptides function. To our knowledge, no conclusive studies have shown direct binding of the EL-targeting peptides with their corresponding connexin sequences. A recent blind docking molecular mechanics modeling approach studying Gap26, Gap27, and "Peptide 5" suggests that the peptide binding site may be unrelated to the connexin-mimetic sequence[146]. Simon et al. suggested that, due to a number of factors including a lack of access to the sites, binding most likely occurs within the inner EL1 surface and EL1-2 interface[146]. Wang et al. also suggested that peptide size may play a role in the inhibition of connexin channels, potentially leading to steric hindrance of the channel[10], although this has been debated for other peptides[112].

The idea of channel block in this manner has been discussed in detail[136], but there is little direct evidence for this mechanism. Gap26 and Gap27 peptides are around 1300-1500 Da in size, and there is evidence to suggest that peptides up to 1800 Da can enter via connexin hemichannels[147]. This leads to the possibility that EL peptides can target protein sites distinct from the EL regions as other connexin-mimetic peptides have been found to bind multiple regions of the same connexin protein[130]. 


\subsection{Connexin mimetic peptides that target the intracellular loop}

A model for the control of GJ (Cx43 and Cx40) channel gating was suggested in studies by Delmar and colleagues, where they described a "ball-and-chain" gating mechanism[148-151]. Their model identified a pH dependent interaction of the flexible connexin-CT with a portion of the connexin-IL[148,150,152]. Based on these studies it was proposed that the connexin-IL acts as a receptor site for regulation of the GJ pore, in that, binding at this site by connexinCT leads to closure of the channel[153]. Using protein interaction studies (ELISA, NMR) based techniques, Delmar et al. identified a connexin-mimetic peptide of the Cx43-IL that binds the Cx43CT, later described as the L2/Cx43L2 peptide (Table 1)[39]. In vitro studies of purified proteins demonstrated that the Cx43L2 peptide and Cx43-CT directly interact in a $\mathrm{pH}$ dependent manner[39].

There is very little sequence homology in the connexin-IL, unlike the -EL regions, therefore peptides are presumably isoform specific. Early peptide studies targeting the Cx43-IL, using peptides within the L2 region, GAP 13 and GAP 15 peptides, required direct injection of the peptides into cells to produce a functional block, due to the inability of the peptide to cross the plasma membrane[113]. Since then, many studies have linked cell penetrating moieties that permit membrane translocation of peptides. The most commonly used forms of these in connexin-mimetic peptide studies has been the HIV-TAT sequence (YGRKKRRQRRR)[152,154], antennapedia sequence (RQPKIWFPNRRKPWKK)[155], and the cell penetrating peptide sequence (LCLRPV) derived from the X-protein of hepatitis B virus[115], added to the NT or CT of each peptide (Table 1). Several studies have demonstrated the effectiveness of these approaches in permitting internalization of the connexin mimetic peptides[111,114,118].

In order to test the functions of the IL-CT interaction in the role of GJ coupling or hemichannel signaling outside of structural studies, several other L2 peptides were developed by Leybaert and colleagues with an attached TAT sequence[111]. In these studies, the authors developed TAT-bound peptides for the Cx50L2 (TAT-Cx50L2) as well as CT peptides for Cx43 and Cx50 (TAT-Cx43CT, TAT-Cx50CT, Table 1). TAT-Cx50L2 peptides produced no effect[111], and the function of the TAT-Cx43CT/-Cx50CT peptides will be discussed in detail later. The studies using TAT-Cx43L2 are reported to be specific to hemichannel functions, indicating that there are differential regulatory pathways for GJ gating[111].

The Gap19 peptide, consisting of 9 amino acids within the Cx43L2 region, was described to alter Cx43, but not Cx40 hemichannels, preventing experimentally induced ischemia reperfusion injury[112], and Cx43 hemichannel function in astrocytes[114]. The first Gap19 iteration, with a molecular weight of around 1100 Da and net charge of +3 , was not attached with a specific internalization sequence, rather it was assumed the "KKFK" sequence permitted plasma membrane translocation as previously described[156]. Later, a TAT-bound Gap19 (TAT-19) was shown to have anti-inflammatory and neuroprotective effects[157]. TAT-Gap19 (Cx43), as well as TAT-GAP24 (same L2 region in Cx32), both block hemichannels reducing acetaminophen induced liver injury[108], limiting $\mathrm{Ca}^{2+}$ activated hemichannel activation, and reducing arrythmias in human heart tissues[158]. Recently, Coutinho et al. developed Xentry-Gap19, which is composed of Gap19 bound by the cell penetrating "LCLRPV" peptide sequence, using Syndecan-4 for entry, potentially making it specific to cells expressing this receptor[115]. Xentry-Gap19 provides a greater hemichannel block than the Gap19 peptide alone, while not altering GJ signaling[115].

The Gap 19 and Cx43L2 peptides can directly bind the Cx43-CT. Ponsaerts et al. identified binding between the Cx43L2 peptide and the Cx43CT peptide containing the last 10 amino acids of Cx43, using surface plasmon resonance (SPR) analysis[111]. Further, Ponsaerts et al. determined that amino acids isoleucine (I130) and histidine (H126) are essential for peptide functions and hemichannel blockade. Interaction studies by Wang et al., using SPR, determined that GAP19, like Cx43L2, interacts with amino acids between 255-382 on the Cx43-CT[112]. SPR data suggest that GAP19 has a stronger interaction with the Cx43-CT ${ }^{255-382}$ than the Cx43L2 peptide[112]. However, the Cx43CT protein used in these studies was longer (127 a.a.) than that used for the Ponsaerts SPR data (10 a.a.)[111], which may indicate different binding modalities or regions for Cx43-CT. A 9 a.a. peptide, Gap20, overlaps Gap19 and includes a.a. I130, but not H126, is biologically inactive and does not alter cellular signaling. Gap20 and another peptide, Gap22 (Cx40-L2 region), were ineffective against the phenylephrine induced $\mathrm{Ca}^{2+}$ oscillations on rabbit arterial sections and vasoconstriction in rat mesenteric arteries[89,116]. Early et al. described a slight depolarization of the rat mesenteric arteries by Gap20, 
potentially as a result of high peptide concentrations of $300 \mu \mathrm{M}[116]$. While these experiments did not include the use of internalization sequences, their small size and charge could potentially allow for uptake through connexin hemichannels (as previously suggested[156]) which may account for these effects.

\subsection{Connexin-mimetic peptides that target the CT}

The intracellular CT regions of connexin proteins regulate a number of functions including, but not limited to, protein trafficking, assembly, and channel gating[159-161]. The connexin-CT is also known as a regulator of cell growth and differentiation that interacts with a number of proteins within the cell[161]. Given the critical connexin functions regulated by the $\mathrm{CT}$, the region has been an attractive target for peptide therapies.

\subsection{1. $\alpha$ CT peptides}

The first biologically active peptide targeting the Cx43 CT was reported in 2005 by the Gourdie laboratory[118]. The alpha carboxyl terminus 1 ( $\alpha \mathrm{CT} 1)$ peptide is a mimetic sequence to the last nine amino acids of the CT of Cx43 (RPRPDDLEI), attached to a 16-amino acid antennapedia sequence for cell internalization, linked to the peptide's Nterminus[118]. Direct protein-peptide interactions have been demonstrated for Cx43 and $\alpha \mathrm{CT} 1$, interacting with the Cx43-CT, Cx43-L2 domains, the second alpha helical region of the Cx43-CT (H2; Figure 1), and the PDZ2 binding domain of zona occludins 1 (ZO1)[130].

As described above, treatment with $\alpha \mathrm{CT} 1$ increases phosphorylation at Cx43-S368 in cultured HeLa cells[117,119]. Further, in cell culture, $\alpha \mathrm{CT} 1$ has been shown to inhibit binding with its protein partner ZO1, increase GJ plaque size and GJ coupling, and decrease hemichannel activity[162]. At the organ level, $\alpha \mathrm{CT} 1$ increases wound closure rates, reduces scarring, and reduces inflammation in skin and retinal wounds[163]. In hearts, $\alpha$ CT1 has been proven effective in mitigating ischemia reperfusion injury in murine models and has antiarrhythmic effects[130]. To date, the $\alpha$ CT1 peptide has shown promising results as a therapy for a variety of conditions at the pre-clinical and clinical levels, including cardiac disease, retinal injury, and wound healing; recently reporting successful phase II clinical trial data on the use of $\alpha \mathrm{CT} 1$ for the treatment of venous leg ulcers and diabetic foot ulcers[45,50,164-168].

Several peptide modifications of $\alpha \mathrm{CT} 1$ also exist. The $\alpha \mathrm{CT} 2$ (also referred to as $\alpha \mathrm{CT} 11$ )[130] peptide consisting of the last nine amino acids of $\mathrm{Cx} 43$, but without an antennapedia sequence, and the $\alpha \mathrm{CT} 3$ peptide consisting of the last $23 \mathrm{Cx} 43-\mathrm{CT}$ amino acids with an antennapedia sequence were found to accelerate wound healing in mice[119]. Though, both peptides were less effective than $\alpha \mathrm{CT} 1$. The $\alpha \mathrm{CT} 11$ peptide has recently been shown to be cardioprotective against ischemia reperfusion injury, preserving left ventricular developed pressure after injury associated with increases in Cx43-S368 phosphorylation[130].

\subsubsection{CT9 Peptide/CT10/TAT-Cx43 Peptides}

Over the last decade, Leybeart and colleagues have published extensively on a peptide referred to as CT9, which is comprised of the same last 9 amino acids of the Cx43 CT found in the $\alpha$ CT11 peptide (Table 1)[98]. Supporting the earlier findings from the Gourdie laboratory's work with $\alpha \mathrm{CT11}$, CT9 was found to block Cx43-ZO1 interactions and to trigger PKC-mediated Cx43-S368 phosphorylation[122,130]. In contrast to earlier works on $\alpha \mathrm{CT11}$, where several studies demonstrated the $\alpha$ CT peptides to block connexin hemichannels[119,169,170], CT9 is reported to acutely activate Cx32 and Cx43 hemichannels[98]. One important difference that may explain these discrepancies is that the $\alpha \mathrm{CT} 11$ effect on hemichannels has been reported over hours or even days, whereas the effect of CT9 was measured over seconds to minutes. This could suggest a potential difference in short- and long-term peptide treatments to the hemichannel activation/inactivation axis.

Several other studies have described effects of two identical peptides covering the last 10 a.a. of the Cx43-CT, referred to as TAT-Cx43CT[111] and TAT-CT10[112]. TAT-Cx43CT maintains to hemichannel opening, allowing for preservation of coordinated $\mathrm{Ca}^{2+}$ signaling in endothelial cells[111]. In their studies, Ponsaerts et al. demonstrated binding between $\mathrm{Cx} 43 \mathrm{CT}$ and the PDZ2 domain of ZO-1 by SPR, with binding lost when using the TAT-Cx43CT $\Delta \mathrm{I}$ peptide that is lacking the last isoleucine[111]. However, ZO1-Cx43CT interaction did not alter peptide-linked 
hemichannel functions in these studies[111]. Both TAT-Cx43CT and TAT-CT10 peptides maintain hemichannel opening, in the presence of Cx43 hemichannel blocker peptides TAT-L2 (Cx43) and GAP19[111,112]. This is thought to occur by peptide disruption of GAP19 binding the Cx43-CT[112]. Ponsaert et al. used SPR to demonstrate that Cx43-L2 and Cx43CT peptides interact, suggesting that inhibition may occur by competition for binding sites on Cx43-L2 region[111]. Studies by Wang et al., produced similar results with SPR analysis demonstrating binding between GAP19 peptide and the Cx43-CT (a.a. 255-382) and the Cx43-IL (a.a. 119-144). Although these studies did not directly demonstrate inhibition/ competition for binding by the TAT-CT10 peptide[112].

\subsection{3. $v S R C / c S R C$}

SRC tyrosine kinases are involved in numerous cell functions, including cell metabolism, and are found in both proliferating and postmitotic cells. The protein exists in both a cellular form (CSRC) and as a viral homologue (vSRC)[171]. cSRC binding with the Cx43-CT results in the inhibition of CSRC. Active cSRC plays a role in perpetuating cancer cell proliferation including in glioma stem cells. Work from the Tabernero laboratory identified a Cx43 peptide spanning amino acids 266 to 283 (TAT-Cx43 266-283) that mimics the SRC SH3 binding domain along with a number of upstream residues[172]. This peptide contains a cell penetrating TAT sequence allowing it to enter the intracellular space and bind cSRC, resulting in cSRC inactivation[172]. In cultured glioblastoma stem cells, obtained from patients, the application of TAT-Cx43 266-283 reduced cSRC activity and limited the glioblastoma phenotype[172]. TAT-Cx43 266-283 treatment in both in vivo mouse models and cultured human glioblastoma stem cells resulted in a reduction in glucose uptake and consumption. This effect was mediated by inactivation of cSRC and a subsequent reduction in hexokinase-2 (HK-2), glucose-6-phosphate dehydrogenase (G6PD), and glucose transporter-3 (GLUT-3) proteins, all of which are involved in the proliferation of glioblastoma stem cells through the uptake and usage of glucose[173].

In neural progenitor cells, cSRC is involved in survival and proliferation via the epidermal growth factor (EGF) and fibroblast growth factor 2 (FGF-2) signaling pathways[174,175]. These progenitor cells, when treated with the Cx43 266-283 peptide in culture, exhibited impaired survival, proliferation, and differentiation rates due to cSRC inhibition. Interestingly, the TAT-Cx43 266-283 peptide increased rates of astrocyte proliferation in culture. The authors hypothesized that this is due to reductions in CSRC leading to a decrease in $\beta$-catenin expression by an unknown mechanism[126].

The interaction between Cx43 and cSRC has also been studied in the context of neuroinflammation. In response to neuroinflammation stimuli, TAT-Cx43 266-283 reduced cSRC levels and exhibited a neuroprotective effect[176]. In these studies, it was proposed that TAT-Cx43 266-283 induced CSRC inhibition interferes with the ability of activated astrocytes to mount an inflammatory response to neuronal injury. Astrocytic hemichannels, including Cx43, were inhibited by TAT-Cx43 266-283 indicating that cSRC mediates hemichannel activation[176].

\subsubsection{JM2 peptide}

The Cx43 juxtamembrane 2 (JM2) connexin-mimetic peptide, published by Calder et al. in 2015, was designed to target amino acids 231-245 of the Cx43 CT, a known microtubule-binding domain[124]. Initial studies, found that JM2 treatment significantly enhanced the $\mathrm{C} \times 43-\beta$-tubulin interaction thought to be important for $\mathrm{C} \times 43$ trafficking. Yet, paradoxically reduces cell surface Cx43 expression and GJ size[177]. Likewise, JM2 decreased GJ and hemichannel activity, as assessed by ATP release assay[124]. In a subsequent study, Rhett et al. speculated that decreased Cx43 channel activity resulted from enhanced $C \times 43-\beta$-tubulin interactions, that led to $C \times 43$ inappropriately 'adhering' to the microtubules as opposed to using them as a trafficking scaffold[20].

In vivo studies in mice and rats demonstrate that JM2 treatment reduces inflammatory cell infiltration following submuscular device implant[124], reduces tumor recurrence following solid tumor resection, and improves wound healing[177]. Further studies have shown that JM2 promotes tumor cell apoptosis in cultured B16F10 and Skov-3 tumor cells and improves migration of cultured endothelial cells[177]. Recent research yielded promising results testing JM2 as a therapy for glioblastoma and there are currently groups looking to use JM2 loaded biodegradable nanoparticles to treat temozolomide resistant glioblastoma, with studies in preparation for clinical trials[178,179]. 


\section{The phosphorylation phenomenon: Cx43-S368 - Phosphorylation as a key factor in the effect of connexin mimetic peptides.}

One observation that bears mentioning in this review is the consistency with which Cx43 peptides induce PKCassociated Cx43-S368 phosphorylation (Table 1). Many of the Cx43 targeting peptides in this review, regardless of site specificity to the EL, IL, or CT, appear to cause intrinsic changes in Cx43 phosphorylation. Phosphorylation of Cx43-CT is a key event in channel open/ close probability, but is also a significant modulator of protein-protein interactions that control protein trafficking and localization as well as non-GJ functions.

There is conflicting information on whether Cx43 PKC-phosphorylation leads to enhanced or reduced GJ coupling[78,157]. Phosphorylation of Cx43 by PKC is reported primarily at Cx43-S368, though five other sites are also reported to be altered, thus it is possible combinations of these phosphorylation sites may occur[78]. Phosphorylation of Cx43-S368 alters the random coil nature of the Cx43-CT and induces a more alpha helical state, associated with reduced GJ formation and signalling[145,180,181]. Phosphorylation by PKC is also reported to alter the nature of Cx43 interactions with ubiquitin ligases and thus its degradation within the cell[182]. While PKC phosphorylation is generally associated with closure of the gap junctions[145,183], several studies have found that peptide treatments (e.g. $\alpha \mathrm{CT} 1)$ enhance PKC $\varepsilon$ phosphorylation of Cx43, leading to increased gap junction stability and communication, but reduced hemichannel opening[122,162]. Similarly, the non-targeting peptides such as AAP10 and danegaptide, all increase Cx43S368 phosphorylation, presumably through GPCR activation, which is reported to increase gap junction communciation[62,69,75,79-81]. As noted by Jiang et al. the $\alpha \mathrm{CT} 1$ and $\alpha \mathrm{CT} 11$ peptides can interact with multiple regions on the Cx43 protein, and with other proteins, that may result in an alteration in accessibility of specific Cx43 amino acids. This may indicate that peptides altering the CT/L2 regions leaving the Cx43-S368 region more susceptible to phosphorylation[130]. Thus, it is possible that connexin mimetic peptide binding induces phosphorylation by altering the structure restraints of the Cx43-CT or by promoting phosphorylation combinations of the multiple suggested Cx43PKC sites, which can result in both increased or decreased gap junction coupling[78].

The overall significance of the Cx43-PKC (S368) phosphorylation following peptide treatments remains to be fully elucidated. As described, many studies have found that peptide-induced Cx43-PKC phosphorylation was associated with improved outcomes, such as mitigated ischemic injury, reduced cellular proliferation in cancer, and improved wound healing. Thus, while highly speculative, it is possible that activating the PKC pathways may be considered cytoprotective.

\section{Connexin peptide cross-reactivity with pannexins}

The "Gap" peptides have shown promise of increased specificity to connexins by comparison to conventional channel blockers such as glycyrrhetinic acid[184]. However, there are serious concerns that they may target related channels and produce off target effects. Recently, ${ }^{33}$ Gap27 and ${ }^{32}$ Gap24 have been found to block pannexin 1 (Panx1) channels at concentrations ranging from $200 \mu \mathrm{M}$ to $2 \mathrm{mM}[10]$. This has led some to debate whether the connexinmimetic peptides are truly sufficiently selective to allow for specific channel identification[10,184]

Pannexins form purine release channels that are structurally homologous to the connexins, but share little sequence homology. The pannexin channels function in a similar manner to that described for connexin hemichannels and are known to release ATP as well as other molecules[185]. Several GJ blockers and non-specific channel blockers inhibit both connexin and pannexin channel release of ATP. This poses a complication with data interpretation, as measures of ATP release, used to assess connexin hemichannel function, are a shared output associated to alterations in pannexin channel activity.

Connexin-mimetic peptides have demonstrated effects on pannexin channels. These peptides are known to attenuate ATP release and $\mathrm{Ca}^{2+}$ waves, associated with both connexin and pannexin channels. Both ${ }^{37,43} \mathrm{Gap} 27$ and ${ }^{32} \mathrm{Gap} 24$ can reversibly inhibit pannexin membrane currents[10]. ${ }^{37,43} \mathrm{Gap} 27$ contains a sequence from an extracellular loop of $\mathrm{Cx} 43$, while ${ }^{32} \mathrm{Gap} 24$ contains a sequence from the intracellular loop of Cx32. Interestingly, scrambled ${ }^{32} \mathrm{Gap} 24$ showed similar levels of inhibition to its non-scrambled counterpart. Polyethyleneglycol 1500 (PEG 1500), an inert, biocompatible polymer inhibited pannexin channels similarly to the connexin-mimetic peptides. This along with the 
inhibitory activity of scrambled ${ }^{32}$ Gap24 peptide suggests inhibition of pannexins by mimetic peptides may functions via steric block of the channel rather than peptide-protein interactions[10].

Multiple Panx1 mimetic peptides have been developed targeting sequences on both the intracellular and extracellular loops. Peptides E1a, E1b, E1c, E2a, and E2b target Panx1 extracellular loop sequences. Both E1b and E1c can inhibit Panx1 channels by more than 10\%, with E1b having the strongest inhibitory effect. The peptide 10Panx1 contains the same sequence as E1b but is three amino acids shorter. Both 10Panx1 and E1b inhibit Panx1 channels to a similar extent[10]. Other Panx1 peptide inhibitors include, PxIL2P that targets Panx1-IL2 developed by Isakson et al.[186,187], and an interfering peptide Panx Y308, which has a target sequence between a.a. 305 and 318 on the C terminus developed by the Thompson lab[188,189].

The peptide 10Panx1 inhibits Panx1 currents compared with its scrambled sequence, suggesting specificity[190192]. However, 10Panx1 has also been found to inhibit Cx46 channels[10]. PxIL2P reportedly targets a Panx1 sequence necessary for Panx1 activation by a1AR signaling[187]. Application of PxIL2P significantly decreases phenylephrineinduced smooth muscle cell constriction in C57BL/6 mice. These effects were similar to those observed in SMC specific Panx1 knockout mice, suggesting that PxIL2P is at least somewhat specific to Panx1 channels[187]. Panx Y308 was created specifically to target the Panx1 Src family kinases (SFK) consensus-like sequence between Panx1 305 and 318. This sequence contains a site at tyrosine Y308 where SFK is believed to phosphorylate Panx1 and causes channel opening in anoxic conditions. Panx Y308 has been shown to attenuate anoxic depolarization of Panx1[188].

\section{Concluding remarks - clinical applications and future approaches}

In the last 25 years, several encouraging lines of evidence have demonstrated that connexin targeting peptides can improve disease outcomes in pre-clinical models of disease; thus, highlighting the potential for peptide therapeutics to enter clinical relevance. These thoughts are further supported by successful early clinical trials, but for many peptides the mechanism of action is still lacking and more translational work is necessary.

Connexin proteins are attractive therapeutic targets given their prevalence in disease, although approaches to target connexins are complicated due to the ubiquitous distribution of the proteins in most tissues. GJs perform critical roles in cardiac conduction, cell proliferation, and migration in normal tissues. Inappropriately reducing the expression of connexins or inhibiting GJ functions can be lethal. Alterations or mutations in vasculature associated connexins, such as Cx37 and Cx40, lead to disturbances in blood vessel relaxation and have knock on effects in other systems leading to alteration in renin secretion and increases in blood pressure. Genetic connexin mutations in humans are rare, but several have been identified. Mutations in Cx43 have been linked with cardiovascular disease[193-197], and Cx26 mutations lead to sensorineural hearing loss[198,199] and keratoderma[200,201]. As a result, systemically targeting reductions in connexin expression provides fairly limited options due to the potential for side effects. However, a greater understanding of disease associated, and potentially redundant, mechanisms may help provide avenues for future therapeutic intervention.

Given a lack of diversity in the extracellular portions of the connexin proteins, it is difficult to envisage a specific targeting molecule (antibody or small molecule) that would not disrupt normal functions of multiple GJ isoforms in tissues such as the heart or vasculature. In addition, tissue penetrance remains an issue for more complex agents such as antibodies. Therefore, with the exception of topical agents, it is likely that advances will require targeting of intracellular portions of the connexin proteins. Advancement of therapeutic targeting of connexins will require extensive characterization of the disease specific changes in protein structure and function.

At present, the instability of peptides severely limits their therapeutic potential. Most peptides have a half-life of seconds to minutes and are quickly degraded by changes in $\mathrm{pH}$, shifts in temperature, and by peptidases, making systemic delivery challenging at best[202]. Chen et al. added the lipid-alkyl groups (C12-Laa) moieties to an extended GAP27 peptides increasing half-life from 145 mins to around 350 mins, which could increase their therapeutic viability[106]. Protecting the peptides from peptidases is another potential option, and can be accomplished through peptide cyclization. This has the advantage of decreasing enzyme breakdown, but may also limit targeting of the peptides by limiting access to active sites and blocking structural based interactions[130]. Cyclization may also be 
limited in peptides containing cysteines, which are found in connexin CT and EL, as the must be removed for the production of disulfides bonds during peptide cyclization.

It is likely that future therapeutic approaches may also require systemic delivery by encapsulation of peptides (such as in exosomes[203]), in a process that allows for tissue specific, and intracellular targeting of the connexin proteins. There is still a general lack of detail on the overall peptide mechanisms that produce their effects. Greater examination of the molecular pathways underlying the peptide effects could help define more specific therapeutics directed at the connexin proteins and their functions and may also allow for the development of peptide-based therapeutics such as small molecule discovery or single domain antibodies targeting these regions.

\section{Author Contributions:}

D.R.K.; M.W.S.; X.L.; J.X; S.L.; M.K.; B.E.I.; S.R.J. writing, draft preparation, review and editing. All authors have read and agreed to the published version of the manuscript."

\section{Funding:}

This research was funded by AHA-CDA 19CDA34630036 (S.R.J.), NIH R01-AA025854 (M.K.), NIH R01-HL137112

(B.E.I., M.K.)

\section{Acknowledgments:}

We thank Anita Impagliazzo for the illustration.

Conflicts of Interest:

The authors declare no conflict of interest 


\section{References}

1. Revel, J.P.; Karnovsky, M.J. Hexagonal array of subunits in intercellular junctions of the mouse heart and liver. J Cel/ Bio/1967, 33, C7-C12.

2. Dewey, M.M.; Barr, L. Intercellular Connection between Smooth Muscle Cells: the Nexus. Science 1962, 137, 670-672, doi:10.1126/science.137.3531.670-a.

3. Robertson, J.D. The occurence of a subunit pattern in the unit membrnanes of club endings in mauthner cell synsapses in goldfish brains. J Cell Bio/ 1963, 19, 201-221.

4. Evans, W.H.; Martin, P.E. Gap junctions: structure and function (Review). Mol Membr Biol 2002, 19, 121-136, doi:10.1080/09687680210139839.

5. Johnstone, S.; Isakson, B.; Locke, D. Biological and biophysical properties of vascular connexin channels. Int Rev Cel/ Mol Biol 2009, 278, 69-118, doi:S1937-6448(09)78002-5 [pii]

10.1016/S1937-6448(09)78002-5.

6. Koval, M.; Molina, S.A.; Burt, J.M. Mix and match: investigating heteromeric and heterotypic gap junction channels in model systems and native tissues. FEBS Lett 2014, 588, 1193-1204, doi:10.1016/j.febslet.2014.02.025.

7. Weber, P.A.; Chang, H.C.; Spaeth, K.E.; Nitsche, J.M.; Nicholson, B.J. The permeability of gap junction channels to probes of different size is dependent on connexin composition and permeant-pore affinities. Biophysical journal 2004, 87, 958-973, doi:10.1529/biophysj.103.036350.

8. Santa Cruz, A.; Meşe, G.; Valiuniene, L.; Brink, P.R.; White, T.W.; Valiunas, V. Altered conductance and permeability of Cx40 mutations associated with atrial fibrillation. J Gen Physio/2015, 146, 387-398, doi:10.1085/jgp.201511475.

9. Kanaporis, G.; Brink, P.R.; Valiunas, V. Gap junction permeability: selectivity for anionic and cationic probes. Am J Physio/ Cell Physio/2011, 300, C600-609, doi:10.1152/ajpcell.00316.2010.

10. Wang, J.; Ma, M.; Locovei, S.; Keane, R.W.; Dahl, G. Modulation of membrane channel currents by gap junction protein mimetic peptides: size matters. Am J Physio/ Cell Physio/2007, 293, C1112-1119, doi:10.1152/ajpcell.00097.2007.

11. Zhu, Y.; Chen, X.; Lu, Y.; Fan, S.; Yang, Y.; Chen, Q.; Huang, Q.; Xia, L.; Wei, Y.; Zheng, J.; et al. Diphenyleneiodonium enhances P2X7 dependent non-opsonized phagocytosis and suppresses inflammasome activation via blocking CX43-mediated ATP leakage. Pharmacol Res 2021, 166, 105470, doi:10.1016/j.phrs.2021.105470.

12. Orellana, J.A.; Froger, N.; Ezan, P.; Jiang, J.X.; Bennett, M.V.; Naus, C.C.; Giaume, C.; Sáez, J.C. ATP and glutamate released via astroglial connexin 43 hemichannels mediate neuronal death through activation of pannexin 1 hemichannels. $J$ Neurochem 2011, 118, 826-840, doi:10.1111/j.1471-4159.2011.07210.x.

13. Huckstepp, R.T.; id Bihi, R.; Eason, R.; Spyer, K.M.; Dicke, N.; Willecke, K.; Marina, N.; Gourine, A.V.; Dale, N. Connexin hemichannel-mediated CO2-dependent release of ATP in the medulla oblongata contributes to central respiratory chemosensitivity. J Physio/2010, 588, 3901-3920, doi:10.1113/jphysiol.2010.192088.

14. Pecoraro, M.; Sorrentino, R.; Franceschelli, S.; Del Pizzo, M.; Pinto, A.; Popolo, A. Doxorubicin-Mediated Cardiotoxicity: Role of Mitochondrial Connexin 43. Cardiovasc Toxico/2015, 15, 366-376, doi:10.1007/s12012-014-9305-8.

15. Fowler, S.L.; Akins, M.; Zhou, H.; Figeys, D.; Bennett, S.A. The liver connexin32 interactome is a novel plasma membranemitochondrial signaling nexus. J Proteome Res 2013, 12, 2597-2610, doi:10.1021/pr301166p.

16. Boengler, K.; Bulic, M.; Schreckenberg, R.; Schlüter, K.D.; Schulz, R. The gap junction modifier ZP1609 decreases cardiomyocyte hypercontracture following ischaemia/reperfusion independent from mitochondrial connexin 43. Br J Pharmaco/2017, 174, 2060-2073, doi:10.1111/bph.13804.

17. Johnstone, S.R.; Best, A.K.; Wright, C.S.; Isakson, B.E.; Errington, R.J.; Martin, P.E. Enhanced Connexin 43 Expression Delays Intra-Mitoitc Duration and Cell Cycle Traverse Independently of Gap Junction Channel Function. Journal of Cellular Biochemistry 2010, 110, 772-782, doi:10.1002/jcb.22590. 
18. Johnstone, S.R.; Kroncke, B.M.; Straub, A.C.; Best, A.K.; Dunn, C.A.; Mitchell, L.A.; Peskova, Y.; Nakamoto, R.K.; Koval, M.; Lo, C.W.; et al. MAPK Phosphorylation of Connexin 43 Promotes Binding of Cyclin E and Smooth Muscle Cell Proliferation. Circulation Research 2012, 111, 201-U205, doi:10.1161/CIRCRESAHA.112.272302.

19. Obert, E.; Strauss, R.; Brandon, C.; Grek, C.; Ghatnekar, G.; Gourdie, R.; Rohrer, B. Targeting the tight junction protein, zonula occludens-1, with the connexin43 mimetic peptide, alphaCT1, reduces VEGF-dependent RPE pathophysiology. Journal of molecular medicine (Berlin, Germany) 2017, 95, 535-552, doi:10.1007/s00109-017-1506-8.

20. Rhett, J.M.; Calder, B.W.; Fann, S.A.; Bainbridge, H.; Gourdie, R.G.; Yost, M.J. Mechanism of action of the anti-inflammatory connexin43 mimetic peptide JM2. Am J Physiol Cell Physio/2017, 313, C314-c326, doi:10.1152/ajpcell.00229.2016.

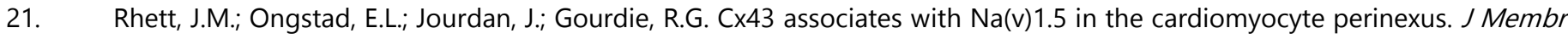
Bio/ 2012, 245, 411-422, doi:10.1007/s00232-012-9465-z.

Barker, R.J.; Price, R.L.; Gourdie, R.G. Increased association of ZO-1 with connexin43 during remodeling of cardiac gap junctions. Circ Res 2002, 90, 317-324.

23. Calhoun, P.J.; Phan, A.V.; Taylor, J.D.; James, C.C.; Padget, R.L.; Zeitz, M.J.; Smyth, J.W. Adenovirus targets transcriptional and posttranslational mechanisms to limit gap junction function. FASEB J2020, 34, 9694-9712, doi:10.1096/fj.202000667R.

James, C.C.; Zeitz, M.J.; Calhoun, P.J.; Lamouille, S.; Smyth, J.W. Altered translation initiation of Gja1 limits gap junction formation during epithelial-mesenchymal transition. Mol Bio/ Cel/2018, doi:10.1091/mbc.E17-06-0406.

Smyth, J.W.; Zhang, S.S.; Sanchez, J.M.; Lamouille, S.; Vogan, J.M.; Hesketh, G.G.; Hong, T.; Tomaselli, G.F.; Shaw, R.M. A 14-33 mode-1 binding motif initiates gap junction internalization during acute cardiac ischemia. Traffic 2014, 15, 684-699, doi:10.1111/tra.12169.

Zeitz, M.J.; Calhoun, P.J.; James, C.C.; Taetzsch, T.; George, K.K.; Robel, S.; Valdez, G.; Smyth, J.W. Dynamic UTR Usage Regulates Alternative Translation to Modulate Gap Junction Formation during Stress and Aging. Cell Rep 2019, 27, 2737-2747.e2735, doi:10.1016/j.celrep.2019.04.114.

27. Smyth, J.W.; Shaw, R.M. Autoregulation of connexin43 gap junction formation by internally translated isoforms. Cell Rep 2013, 5, 611-618, doi:10.1016/j.celrep.2013.10.009.

28. Epifantseva, I.; Xiao, S.; Baum, R.E.; Kléber, A.G.; Hong, T.; Shaw, R.M. An Alternatively Translated Connexin 43 Isoform, GJA111k, Localizes to the Nucleus and Can Inhibit Cell Cycle Progression. Biomolecules 2020, 10, doi:10.3390/biom10030473.

29. Johnstone, S.R.; Billaud, M.; Lohman, A.W.; Taddeo, E.P.; Isakson, B.E. Posttranslational Modifications in Connexins and Pannexins. Journal of Membrane Biology 2012, 245, 319-332, doi:10.1007/s00232-012-9453-3.

30. Aasen, T.; Johnstone, S.; Vidal-Brime, L.; Lynn, K.S.; Koval, M. Connexins: Synthesis, Post-Translational Modifications, and Trafficking in Health and Disease. Int J Mol Sci2018, 19, doi:10.3390/ijms19051296.

31. Jacobsen, N.L.; Pontifex, T.K.; Li, H.; Solan, J.L.; Lampe, P.D.; Sorgen, P.L.; Burt, J.M. Regulation of Cx37 channel and growthsuppressive properties by phosphorylation. J Cell Sci 2017, 130, 3308-3321, doi:10.1242/jcs.202572.

32. Liu, J.; Ek Vitorin, J.F.; Weintraub, S.T.; Gu, S.; Shi, Q.; Burt, J.M.; Jiang, J.X. Phosphorylation of connexin 50 by protein kinase A enhances gap junction and hemichannel function. J Bio/ Chem 2011, 286, 16914-16928, doi:10.1074/jbc.M111.218735.

33. Lampe, P.D.; Cooper, C.D.; King, T.J.; Burt, J.M. Analysis of Connexin43 phosphorylated at S325, S328 and S330 in normoxic and ischemic heart. J Cell Sci2006, 119, 3435-3442, doi:10.1242/jcs.03089.

34. Cottrell, G.T.; Lin, R.; Warn-Cramer, B.J.; Lau, A.F.; Burt, J.M. Mechanism of v-Src- and mitogen-activated protein kinaseinduced reduction of gap junction communication. Am J Physiol Cell Physiol 2003, 284, C511-520, doi:10.1152/ajpcell.00214.2002.

35. Solan, J.L.; Marquez-Rosado, L.; Sorgen, P.L.; Thornton, P.J.; Gafken, P.R.; Lampe, P.D. Phosphorylation at S365 is a gatekeeper event that changes the structure of Cx43 and prevents down-regulation by PKC. J Cell Bio/ 2007, 179, 1301-1309, doi:10.1083/jcb.200707060. 
36. Locke, D.; Bian, S.; Li, H.; Harris, A.L. Post-translational modifications of connexin26 revealed by mass spectrometry. Biochem J2009, 424, 385-398, doi:10.1042/BJ20091140.

37. Bouvier, D.; Kieken, F.; Kellezi, A.; Sorgen, P.L. Structural changes in the carboxyl terminus of the gap junction protein connexin 40 caused by the interaction with c-Src and zonula occludens-1. Cell Commun Adhes 2008, 15, 107-118, doi:10.1080/15419060802014347.

38. Bouvier, D.; Spagnol, G.; Chenavas, S.; Kieken, F.; Vitrac, H.; Brownell, S.; Kellezi, A.; Forge, V.; Sorgen, P.L. Characterization of the structure and intermolecular interactions between the connexin40 and connexin43 carboxyl-terminal and cytoplasmic loop domains. J Biol Chem 2009, 284, 34257-34271, doi:10.1074/jbc.M109.039594.

39. Duffy, H.S.; Sorgen, P.L.; Girvin, M.E.; O'Donnell, P.; Coombs, W.; Taffet, S.M.; Delmar, M.; Spray, D.C. pH-dependent intramolecular binding and structure involving Cx43 cytoplasmic domains. J Biol Chem 2002, 277, 36706-36714, doi:10.1074/jbc.M207016200.

40. Grosely, R.; Kieken, F.; Sorgen, P.L. ${ }^{1} \mathrm{H},{ }^{13} \mathrm{C}$, and ${ }^{15} \mathrm{~N}$ backbone resonance assignments of the connexin43 carboxyl terminal domain attached to the 4th transmembrane domain in detergent micelles. Biomol NMR Assign 2013, 7, 299-303, doi:10.1007/s12104-012-9432-8.

41. Sorgen, P.L.; Duffy, H.S.; Cahill, S.M.; Coombs, W.; Spray, D.C.; Delmar, M.; Girvin, M.E. Sequence-specific resonance assignment of the carboxyl terminal domain of Connexin43. J Biomol NMR 2002, 23, 245-246.

42. Sorgen, P.L.; Duffy, H.S.; Spray, D.C.; Delmar, M. pH-dependent dimerization of the carboxyl terminal domain of Cx43. Biophys J 2004, 87, 574-581, doi:10.1529/biophysj.103.039230.

43. Faniku, C.; O'Shaughnessy, E.; Lorraine, C.; Johnstone, S.R.; Graham, A.; Greenhough, S.; Martin, P.E.M. The Connexin Mimetic Peptide Gap27 and Cx43-Knockdown Reveal Differential Roles for Connexin43 in Wound Closure Events in Skin Model Systems. Int J Mol Sci2018, 19, doi:10.3390/ijms19020604.

44. Greer, K.; Chen, J.; Brickler, T.; Gourdie, R.; Theus, M.H. Modulation of gap junction-associated Cx43 in neural stem/progenitor cells following traumatic brain injury. Brain research bulletin 2017, 134, 38-46, doi:10.1016/j.brainresbull.2017.06.016.

45. Montgomery, J.; Ghatnekar, G.S.; Grek, C.L.; Moyer, K.E.; Gourdie, R.G. Connexin 43-Based Therapeutics for Dermal Wound Healing. Int J Mo/ Sci 2018, 19, doi:10.3390/ijms19061778.

46. Palatinus, J.A.; Gourdie, R.G. Diabetes Increases Cryoinjury Size with Associated Effects on Cx43 Gap Junction Function and Phosphorylation in the Mouse Heart. Journal of diabetes research 2016, 2016, 8789617, doi:10.1155/2016/8789617.

47. BEVAN, J.A.; SU, C. THE SYMPATHETIC MECHANISM IN THE ISOLATED PULMONARY ARTERY OF THE RABBIT. Br J Pharmacol Chemother 1964, 22, 176-182.

48. Dhein, S.; Larsen, B.D.; Petersen, J.S.; Mohr, F.W. Effects of the new antiarrhythmic peptide ZP123 on epicardial activation and repolarization pattern. Cell Commun Adhes 2003, 10,371-378.

49. Engstrøm, T.; Nepper-Christensen, L.; Helqvist, S.; Kløvgaard, L.; Holmvang, L.; Jørgensen, E.; Pedersen, F.; Saunamaki, K.; Tilsted, H.-H.; Steensberg, A.; et al. A phase 2 randomised trial of danegaptide for primary $\mathrm{PCl}$ in

patients with ST-segment Elevation Myocardial Infarction. Heart 2018.

50. Grek, C.L.; Montgomery, J.; Sharma, M.; Ravi, A.; Rajkumar, J.S.; Moyer, K.E.; Gourdie, R.G.; Ghatnekar, G.S. A Multicenter Randomized Controlled Trial Evaluating a Cx43-Mimetic Peptide in Cutaneous Scarring. J Invest Dermato/2017, 137, 620630, doi:10.1016/j.jid.2016.11.006.

51. Evans, W.H.; Leybaert, L. Mimetic peptides as blockers of connexin channel-facilitated intercellular communication. Cell Commun Adhes 2007, 14, 265-273, doi:10.1080/15419060801891034.

52. Leybaert, L.; Lampe, P.D.; Dhein, S.; Kwak, B.R.; Ferdinandy, P.; Beyer, E.C.; Laird, D.W.; Naus, C.C.; Green, C.R.; Schulz, R. Connexins in Cardiovascular and Neurovascular Health and Disease: Pharmacological Implications. Pharmacol Rev 2017, 69, 396-478, doi:10.1124/pr.115.012062. 
53. Schulz, R.; Görge, P.M.; Görbe, A.; Ferdinandy, P.; Lampe, P.D.; Leybaert, L. Connexin 43 is an emerging therapeutic target in ischemia/reperfusion injury, cardioprotection and neuroprotection. Pharmacol Ther 2015, 153, 90-106, doi:10.1016/j.pharmthera.2015.06.005.

54. Giaume, C.; Leybaert, L.; Naus, C.C.; Saez, J.C. Connexin and pannexin hemichannels in brain glial cells: properties, pharmacology, and roles. Front Pharmaco/2013, 4, 88, doi:10.3389/fphar.2013.00088.

55. De Vuyst, E.; Boengler, K.; Antoons, G.; Sipido, K.R.; Schulz, R.; Leybaert, L. Pharmacological modulation of connexin-formed channels in cardiac pathophysiology. Br J Pharmaco/2011, 163, 469-483, doi:10.1111/j.1476-5381.2011.01244.x.

56. Marsh, S.R.; Williams, Z.J.; Pridham, K.J.; Gourdie, R.G. Peptidic Connexin43 Therapeutics in Cardiac Reparative Medicine. J Cardiovasc Dev Dis 2021, 8, doi:10.3390/jcdd8050052.

57. Green, C.R.; Severs, N.J. Gap junction connexon configuration in rapidly frozen myocardium and isolated intercalated disks. J Cell Biol 1984, 99, 453-463, doi:10.1083/jcb.99.2.453.

58. Dunn, C.A.; Lampe, P.D. Injury-triggered Akt phosphorylation of Cx43: a ZO-1-driven molecular switch that regulates gap junction size. J Cell Sci2014, 127, 455-464, doi:10.1242/jcs.142497.

59. Jeyaraman, M.M.; Srisakuldee, W.; Nickel, B.E.; Kardami, E. Connexin43 phosphorylation and cytoprotection in the heart. Biochim Biophys Acta 2012, 1818, 2009-2013, doi:10.1016/j.bbamem.2011.06.023.

60. George, S.A.; Hoeker, G.; Calhoun, P.J.; Entz, M., 2nd; Raisch, T.B.; King, D.R.; Khan, M.; Baker, C.; Gourdie, R.G.; Smyth, J.W.; et al. Modulating cardiac conduction during metabolic ischemia with perfusate sodium and calcium in guinea pig hearts. $\mathrm{Am} J$ Physiol Heart Circ Physio/2019, 316, H849-H861, doi:10.1152/ajpheart.00083.2018.

61. Aonuma, S.; Kohama, Y.; Akai, K.; Komiyama, Y.; Nakajima, S.; Wakabayashi, M.; Makino, T. Studies on heart. XIX. Isolation of an atrial peptide that improves the rhythmicity of cultured myocardial cell clusters. Chem Pharm Bull (Tokyo) 1980, 28, 33323339, doi:10.1248/cpb.28.3332.

62. Jozwiak, J.; Dhein, S. Local effects and mechanisms of antiarrhythmic peptide AAP10 in acute regional myocardial ischemia: electrophysiological and molecular findings. Naunyn-Schmiedeberg's archives of pharmacology 2008, 378, 459-470, doi:10.1007/s00210-008-0317-4.

63. Quan, X.Q.; Bai, R.; Liu, N.; Chen, B.D.; Zhang, C.T. Increasing gap junction coupling reduces transmural dispersion of repolarization and prevents torsade de pointes in rabbit LQT3 model. J Cardiovasc Electrophysio/ 2007, 18, 1184-1189, doi:10.1111/j.1540-8167.2007.00923.x.

64. Quan, X.Q.; Bai, R.; Lu, J.G.; Patel, C.; Liu, N.; Ruan, Y.; Chen, B.D.; Ruan, L.; Zhang, C.T. Pharmacological enhancement of cardiac gap junction coupling prevents arrhythmias in canine LQT2 model. Cell Commun Adhes 2009, 16, 29-38, doi:10.1080/15419060903118567.

65. Axelsen, L.N.; Stahlhut, M.; Mohammed, S.; Larsen, B.D.; Nielsen, M.S.; Holstein-Rathlou, N.H.; Andersen, S.; Jensen, O.N.; Hennan, J.K.; Kjolbye, A.L. Identification of ischemia-regulated phosphorylation sites in connexin43: A possible target for the antiarrhythmic peptide analogue rotigaptide (ZP123). Journal of molecular and cellular cardiology 2006, 40, 790-798, doi:10.1016/j.yjmcc.2006.03.005.

66. Skyschally, A.; Walter, B.; Schultz Hansen, R.; Heusch, G. The antiarrhythmic dipeptide ZP1609 (danegaptide) when given at reperfusion reduces myocardial infarct size in pigs. Naunyn-Schmiedeberg's archives of pharmacology 2013, 386, 383-391, doi:10.1007/s00210-013-0840-9.

67. Hennan, J.K.; Swillo, R.E.; Morgan, G.A.; Keith, J.C.; Schaub, R.G.; Smith, R.P.; Feldman, H.S.; Haugan, K.; Kantrowitz, J.; Wang, P.J.; et al. Rotigaptide (ZP123) prevents spontaneous ventricular arrhythmias and reduces infarct size during myocardial ischemia/reperfusion injury in open-chest dogs. J Pharmacol Exp Ther 2006, 317, 236-243, doi:10.1124/jpet.105.096933.

68. Johnstone, S.R.; Isakson, B.E. 'Gaps' in targeted ischaemic injury therapies in ST-elevation myocardial infarction. Heart 2018, 104, 1557-1558, doi:10.1136/heartjnl-2018-313084. 
69. Easton, J.A.; Petersen, J.S.; Martin, P.E. The anti-arrhythmic peptide AAP10 remodels Cx43 and Cx40 expression and function. Naunyn Schmiedebergs Arch Pharmaco/2009, 380, 11-24, doi:10.1007/s00210-009-0411-2.

70. Clarke, T.C.; Williams, O.J.; Martin, P.E.; Evans, W.H. ATP release by cardiac myocytes in a simulated ischaemia model: inhibition by a connexin mimetic and enhancement by an antiarrhythmic peptide. European journal of pharmacology 2009, 605, 9-14, doi:10.1016/j.ejphar.2008.12.005.

71. Patin, J.; Castro, C.; Steenman, M.; Hivonnait, A.; Carcouët, A.; Tessier, A.; Lebreton, J.; Bihouée, A.; Donnart, A.; Le Marec, H.; et al. Gap-134, a Connexin43 activator, prevents age-related development of ventricular fibrosis in Scn5a. Pharmacol Res 2020, 159, 104922, doi:10.1016/j.phrs.2020.104922.

72. Squires, P.E.; Price, G.W.; Mouritzen, U.; Potter, J.A.; Williams, B.M.; Hills, C.E. Danegaptide Prevents TGF $\beta 1$-Induced Damage in Human Proximal Tubule Epithelial Cells of the Kidney. Int J Mo/ Sci 2021, 22, doi:10.3390/ijms22062809.

73. Weng, S.; Lauven, M.; Schaefer, T.; Polontchouk, L.; Grover, R.; Dhein, S. Pharmacological modification of gap junction coupling by an antiarrhythmic peptide via protein kinase C activation. FASEB J2002, 16, 1114-1116, doi:10.1096/fj.01-0918fje.

74. Dhein, S.; Weng, S.; Grover, R.; Tudyka, T.; Gottwald, M.; Schaefer, T.; Polontchouk, L. Protein kinase Calpha mediates the effect of antiarrhythmic peptide on gap junction conductance. Cell Commun Adhes 2001, 8, 257-264, doi:10.3109/15419060109080734.

75. Stahlhut, M.; Petersen, J.S.; Hennan, J.K.; Ramirez, M.T. The antiarrhythmic peptide rotigaptide (ZP123) increases connexin 43 protein expression in neonatal rat ventricular cardiomyocytes. Cell Commun Adhes 2006, 13, 21-27, doi:10.1080/15419060600631375.

76. Haugan, K.; Kjølbye, A.L.; Hennan, J.K.; Petersen, J.S. Rotigaptide (ZP123) reverts established atrial conduction velocity slowing. Cell Commun Adhes 2005, 12, 271-278, doi:10.1080/15419060500514135.

77. Xue, J.; Yan, X.; Yang, Y.; Chen, M.; Wu, L.; Gou, Z.; Sun, Z.; Talabieke, S.; Zheng, Y.; Luo, D. Connexin 43 dephosphorylation contributes to arrhythmias and cardiomyocyte apoptosis in ischemia/reperfusion hearts. Basic Res Cardio/ 2019, 114, 40, doi:10.1007/s00395-019-0748-8.

78. Alstrom, J.S.; Stroemlund, L.W.; Nielsen, M.S.; MacAulay, N. Protein kinase C-dependent regulation of connexin43 gap junctions and hemichannels. Biochem Soc Trans 2015, 43, 519-523, doi:10.1042/BST20150040.

79. Doble, B.W.; Dang, X.; Ping, P.; Fandrich, R.R.; Nickel, B.E.; Jin, Y.; Cattini, P.A.; Kardami, E. Phosphorylation of serine 262 in the gap junction protein connexin-43 regulates DNA synthesis in cell-cell contact forming cardiomyocytes. J Cel/ Sci 2004, 117, 507-514, doi:10.1242/jcs.00889 117/3/507 [pii].

80. Doble, B.W.; Ping, P.; Kardami, E. The epsilon subtype of protein kinase $C$ is required for cardiomyocyte connexin-43 phosphorylation. Circ Res 2000, 86, 293-301.

81. Grover, R.; Dhein, S. Structure-activity relationships of novel peptides related to the antiarrhythmic peptide AAP10 which reduce the dispersion of epicardial action potential duration. Peptides 2001, 22, 1011-1021.

82. Aasen, T.; Mesnil, M.; Naus, C.C.; Lampe, P.D.; Laird, D.W. Gap junctions and cancer: communicating for 50 years. Nat Rev Cancer 2017, 17, 74, doi:10.1038/nrc.2016.142.

83. Kim, D.; Mouritzen, U.; Larsen, B.D.; Roy, S. Inhibition of Cx43 gap junction uncoupling prevents high glucose-induced apoptosis and reduces excess cell monolayer permeability in retinal vascular endothelial cells. Exp Eye Res 2018, 173, 85-90, doi:10.1016/j.exer.2018.05.003.

84. Freitas-Andrade, M.; Bechberger, J.; Wang, J.; Yeung, K.K.C.; Whitehead, S.N.; Hansen, R.S.; Naus, C.C. Danegaptide Enhances Astrocyte Gap Junctional Coupling and Reduces Ischemic Reperfusion Brain Injury in Mice. Biomolecules 2020, 10, doi:10.3390/biom 10030353 .

85. DeLalio, L.J.; Isakson, B.E. ZP1609/danegaptide and mitochondrial connexin hemichannels: a harbinger for peptide drug design. Br J Pharmaco/2017, 174, 2606-2607, doi:10.1111/bph.13891. 
86. Yu, J.; Lin, Y.H.; Yang, L.; Huang, C.C.; Chen, L.; Wang, W.C.; Chen, G.W.; Yan, J.; Sawettanun, S.; Lin, C.H. Improved Anticancer Photothermal Therapy Using the Bystander Effect Enhanced by Antiarrhythmic Peptide Conjugated Dopamine-Modified Reduced Graphene Oxide Nanocomposite. Adv Healthc Mater 2017, 6, doi:10.1002/adhm.201600804.

87. Yang, W.; Lampe, P.D.; Kensel-Hammes, P.; Hesson, J.; Ware, C.B.; Crisa, L.; Cirulli, V. Connexin 43 Functions as a Positive Regulator of Stem Cell Differentiation into Definitive Endoderm and Pancreatic Progenitors. iScience 2019, 19, 450-460, doi:10.1016/j.isci.2019.07.033.

88. Chen, K.; Chen, L.; Ouyang, Y.; Zhang, L.; Li, X.; Li, L.; Si, J.; Wang, L.; Ma, K. Pirfenidone attenuates homocysteine-induced apoptosis by regulating the connexin 43 pathway in H9C2 cells. Int J Mol Med 2020, 45, 1081-1090, doi:10.3892/ijmm.2020.4497.

89. Chaytor, A.T.; Evans, W.H.; Griffith, T.M. Peptides homologous to extracellular loop motifs of connexin 43 reversibly abolish rhythmic contractile activity in rabbit arteries. J Physio/ 1997, 503 (Pt 1), 99-110, doi:10.1111/j.1469-7793.1997.099bi.x.

90. Chaytor, A.T.; Martin, P.E.; Evans, W.H.; Randall, M.D.; Griffith, T.M. The endothelial component of cannabinoid-induced relaxation in rabbit mesenteric artery depends on gap junctional communication. J Physiol 1999, 520 Pt 2, 539-550, doi:10.1111/j.1469-7793.1999.00539.x.

91. Chaytor, A.T.; Martin, P.E.; Edwards, D.H.; Griffith, T.M. Gap junctional communication underpins EDHF-type relaxations evoked by $\mathrm{ACh}$ in the rat hepatic artery. Am J Physiol Heart Circ Physiol 2001, 280, H2441-2450, doi:10.1152/ajpheart.2001.280.6.H2441.

92. Ju, H.; Wang, Y.; Shi, Q.; Zhou, Y.; Ma, R.; Wu, P.; Fang, H. Inhibition of connexin 43 hemichannels improves postoperative cognitive function in aged mice. Am J Trans/ Res 2019, 11, 2280-2287.

93. Wright, C.S.; van Steensel, M.A.; Hodgins, M.B.; Martin, P.E. Connexin mimetic peptides improve cell migration rates of human epidermal keratinocytes and dermal fibroblasts in vitro. Wound Repair Regen 2009, 17, 240-249, doi:10.1111/j.1524475X.2009.00471.x.

94. Eugenín, E.A.; González, H.; Sáez, C.G.; Sáez, J.C. Gap junctional communication coordinates vasopressin-induced glycogenolysis in rat hepatocytes. Am J Physio/ 1998, 274, G1109-1116, doi:10.1152/ajpgi.1998.274.6.G1109.

95. Mendoza-Naranjo, A.; Saéz, P.J.; Johansson, C.C.; Ramírez, M.; Mandakovic, D.; Pereda, C.; López, M.N.; Kiessling, R.; Sáez, J.C.; Salazar-Onfray, F. Functional gap junctions facilitate melanoma antigen transfer and cross-presentation between human dendritic cells. J Immuno/2007, 178, 6949-6957, doi:10.4049/jimmunol.178.11.6949.

96. Kwak, B.R.; Jongsma, H.J. Selective inhibition of gap junction channel activity by synthetic peptides. J Physio/1999, 516 ( Pt 3), 679-685, doi:10.1111/j.1469-7793.1999.0679u.x.

97. Martin, P.E.; Wall, C.; Griffith, T.M. Effects of connexin-mimetic peptides on gap junction functionality and connexin expression in cultured vascular cells. Br J Pharmaco/2005, 144, 617-627, doi:10.1038/sj.bjp.0706102.

98. De Bock, M.; Wang, N.; Bol, M.; Decrock, E.; Ponsaerts, R.; Bultynck, G.; Dupont, G.; Leybaert, L. Connexin 43 hemichannels contribute to cytoplasmic Ca2 + oscillations by providing a bimodal Ca2+-dependent Ca2 + entry pathway. J Bio/ Chem 2012, 287, 12250-12266, doi:10.1074/jbc.M111.299610.

99. Sahli, K.A.; Flora, G.D.; Sasikumar, P.; Maghrabi, A.H.; Holbrook, L.M.; AlOuda, S.K.; Elgheznawy, A.; Sage, T.; Stainer, A.R.; Adiyaman, R.; et al. Structural, functional, and mechanistic insights uncover the fundamental role of orphan connexin-62 in platelets. Blood 2021, 137, 830-843, doi:10.1182/blood.2019004575.

100. O'Carroll, S.J.; Alkadhi, M.; Nicholson, L.F.; Green, C.R. Connexin 43 mimetic peptides reduce swelling, astrogliosis, and neuronal cell death after spinal cord injury. Cell Commun Adhes 2008, 15, 27-42, doi:10.1080/15419060802014164.

101. Danesh-Meyer, H.V.; Kerr, N.M.; Zhang, J.; Eady, E.K.; O'Carroll, S.J.; Nicholson, L.F.; Johnson, C.S.; Green, C.R. Connexin43 mimetic peptide reduces vascular leak and retinal ganglion cell death following retinal ischaemia. Brain 2012, 135, 506-520, doi:10.1093/brain/awr338. 
102. Mao, Y.; Nguyen, T.; Tonkin, R.S.; Lees, J.G.; Warren, C.; O'Carroll, S.J.; Nicholson, L.F.B.; Green, C.R.; Moalem-Taylor, G.; Gorrie, C.A. Characterisation of Peptide5 systemic administration for treating traumatic spinal cord injured rats. Exp Brain Res 2017, 235, 3033-3048, doi:10.1007/s00221-017-5023-3.

103. Mao, Y.; Tonkin, R.S.; Nguyen, T.; O'Carroll, S.J.; Nicholson, L.F.; Green, C.R.; Moalem-Taylor, G.; Gorrie, C.A. Systemic Administration of Connexin43 Mimetic Peptide Improves Functional Recovery after Traumatic Spinal Cord Injury in Adult Rats. J Neurotrauma 2017, 34, 707-719, doi:10.1089/neu.2016.4625.

104. Cotter, M.L.; Boitano, S.; Lampe, P.D.; Solan, J.L.; Vagner, J.; Ek-Vitorin, J.F.; Burt, J.M. The lipidated connexin mimetic peptide SRPTEKT-. Am J Physio/ Cell Physio/2019, 317, C825-C842, doi:10.1152/ajpcell.00160.2019.

105. Cotter, M.L.; Boitano, S.; Vagner, J.; Burt, J.M. Lipidated connexin mimetic peptides potently inhibit gap junction-mediated Ca. Am J Physiol Cell Physio/ 2018, 315, C141-C154, doi:10.1152/ajpcell.00156.2017.

106. Chen, Y.S.; Toth, I.; Danesh-Meyer, H.V.; Green, C.R.; Rupenthal, I.D. Cytotoxicity and vitreous stability of chemically modified connexin43 mimetic peptides for the treatment of optic neuropathy. J Pharm Sci 2013, 102, 2322-2331, doi:10.1002/jps.23617.

107. De Vuyst, E.; Decrock, E.; Cabooter, L.; Dubyak, G.R.; Naus, C.C.; Evans, W.H.; Leybaert, L. Intracellular calcium changes trigger connexin 32 hemichannel opening. EMBO J2006, 25, 34-44, doi:10.1038/sj.emboj.7600908.

108. Maes, M.; Crespo Yanguas, S.; Willebrords, J.; Weemhoff, J.L.; da Silva, T.C.; Decrock, E.; Lebofsky, M.; Pereira, I.V.A.; Leybaert, L.; Farhood, A.; et al. Connexin hemichannel inhibition reduces acetaminophen-induced liver injury in mice. Toxicol Lett 2017, 278, 30-37, doi:10.1016/j.toxlet.2017.07.007.

109. Seki, A.; Duffy, H.S.; Coombs, W.; Spray, D.C.; Taffet, S.M.; Delmar, M. Modifications in the biophysical properties of connexin43 channels by a peptide of the cytoplasmic loop region. Circ Res 2004, 95, e22-28, doi:10.1161/01.RES.0000140737.62245.c5.

110. Seki, A.; Coombs, W.; Taffet, S.M.; Delmar, M. Loss of electrical communication, but not plaque formation, after mutations in the cytoplasmic loop of connexin43. Heart Rhythm 2004, 1, 227-233, doi:10.1016/j.hrthm.2004.03.066.

111. Ponsaerts, R.; De Vuyst, E.; Retamal, M.; D'Hondt, C.; Vermeire, D.; Wang, N.; De Smedt, H.; Zimmermann, P.; Himpens, B.; Vereecke, J.; et al. Intramolecular loop/tail interactions are essential for connexin 43-hemichannel activity. FASEB J 2010, 24, 4378-4395, doi:fj.09-153007 [pii] 10.1096/fj.09-153007.

112. Wang, N.; De Vuyst, E.; Ponsaerts, R.; Boengler, K.; Palacios-Prado, N.; Wauman, J.; Lai, C.P.; De Bock, M.; Decrock, E.; Bol, M.; et al. Selective inhibition of $\mathrm{C} \times 43$ hemichannels by Gap19 and its impact on myocardial ischemia/reperfusion injury. Basic Res Cardio/2013, 108, 309, doi:10.1007/s00395-012-0309-x.

113. Becker, D.L.; Evans, W.H.; Green, C.R.; Warner, A. Functional analysis of amino acid sequences in connexin43 involved in intercellular communication through gap junctions. J Cell Sci 1995, 108 ( Pt 4), 1455-1467.

114. Abudara, V.; Bechberger, J.; Freitas-Andrade, M.; De Bock, M.; Wang, N.; Bultynck, G.; Naus, C.C.; Leybaert, L.; Giaume, C. The connexin43 mimetic peptide Gap19 inhibits hemichannels without altering gap junctional communication in astrocytes. Front Cell Neurosci 2014, 8, 306, doi:10.3389/fncel.2014.00306.

115. Coutinho, F.P.; Green, C.R.; Acosta, M.L.; Rupenthal, I.D. Xentry-Gap19 inhibits Connexin43 hemichannel opening especially during hypoxic injury. Drug Deliv Trans/ Res 2020, 10, 751-765, doi:10.1007/s13346-020-00763-y.

116. Earley, S.; Resta, T.C.; Walker, B.R. Disruption of smooth muscle gap junctions attenuates myogenic vasoconstriction of mesenteric resistance arteries. Am J Physiol Heart Circ Physio/ 2004, 287, H2677-2686, doi:10.1152/ajpheart.00016.2004.

117. Palatinus, J.A.; Rhett, J.M.; Gourdie, R.G. Enhanced PKCepsilon mediated phosphorylation of connexin43 at serine 368 by a carboxyl-terminal mimetic peptide is dependent on injury. Channels (Austin) 2011, 5, 236-240.

118. Hunter, A.W.; Barker, R.J.; Zhu, C.; Gourdie, R.G. Zonula occludens-1 alters connexin43 gap junction size and organization by influencing channel accretion. Mol Biol Cel/ 2005, 16, 5686-5698, doi:10.1091/mbc.e05-08-0737. 
119. Ghatnekar, G.S.; O'Quinn, M.P.; Jourdan, L.J.; Gurjarpadhye, A.A.; Draughn, R.L.; Gourdie, R.G. Connexin43 carboxyl-terminal peptides reduce scar progenitor and promote regenerative healing following skin wounding. Regen Med 2009, 4, 205-223, doi:10.2217/17460751.4.2.205.

120. Jiang, J.; Hoagland, D.; Palatinus, J.A.; He, H.; lyyathurai, J.; Jourdan, L.J.; Bultynck, G.; Wang, Z.; Zhang, Z.; Schey, K.; et al. Interaction of alpha Carboxyl Terminus 1 Peptide With the Connexin 43 Carboxyl Terminus Preserves Left Ventricular Function After Ischemia-Reperfusion Injury. J Am Heart Assoc 2019, 8, e012385, doi:10.1161/JAHA.119.012385.

121. Bond, S.R.; Wang, N.; Leybaert, L.; Naus, C.C. Pannexin 1 ohnologs in the teleost lineage. J Membr Bio/ 2012, 245, 483-493, doi:10.1007/s00232-012-9497-4.

122. O'Quinn, M.P.; Palatinus, J.A.; Harris, B.S.; Hewett, K.W.; Gourdie, R.G. A peptide mimetic of the connexin43 carboxyl terminus reduces gap junction remodeling and induced arrhythmia following ventricular injury. Circulation Research 2011, 108, 704715, doi:10.1161/circresaha.110.235747.

123. Verma, V.; Larsen, B.D.; Coombs, W.; Lin, X.; Sarrou, E.; Taffet, S.M.; Delmar, M. Design and characterization of the first peptidomimetic molecule that prevents acidification-induced closure of cardiac gap junctions. Heart Rhythm 2010, 7, 14911498, doi:10.1016/j.hrthm.2010.06.028.

124. Calder, B.W.; Matthew Rhett, J.; Bainbridge, H.; Fann, S.A.; Gourdie, R.G.; Yost, M.J. Inhibition of connexin 43 hemichannelmediated ATP release attenuates early inflammation during the foreign body response. Tissue Eng Part A 2015, 21, 17521762, doi:10.1089/ten.TEA.2014.0651.

125. Pelaz, S.G.; Jaraíz-Rodríguez, M.; Álvarez-Vázquez, A.; Talaverón, R.; García-Vicente, L.; Flores-Hernández, R.; Gómez de Cedrón, M.; Tabernero, M.; Ramírez de Molina, A.; Lillo, C.; et al. Targeting metabolic plasticity in glioma stem cells in vitro and in vivo through specific inhibition of C-Src by TAT-Cx43. EBioMedicine 2020, 62, 103134, doi:10.1016/j.ebiom.2020.103134.

126. Talaverón, R.; Matarredona, E.R.; Herrera, A.; Medina, J.M.; Tabernero, A. Connexin43 Region 266-283, via Src Inhibition, Reduces Neural Progenitor Cell Proliferation Promoted by EGF and FGF-2 and Increases Astrocytic Differentiation. Int $J$ Mo/ Sci2020, 21, doi:10.3390/ijms21228852.

127. Meyer, R.A.; Laird, D.W.; Revel, J.P.; Johnson, R.G. Inhibition of gap junction and adherens junction assembly by connexin and A-CAM antibodies. J Cell Biol 1992, 119, 179-189, doi:10.1083/jcb.119.1.179.

128. Goodenough, D.A.; Paul, D.L.; Jesaitis, L. Topological distribution of two connexin32 antigenic sites in intact and split rodent hepatocyte gap junctions. J Cell Bio/ 1988, 107, 1817-1824, doi:10.1083/jcb.107.5.1817.

129. Dahl, G.; Nonner, W.; Werner, R. Attempts to define functional domains of gap junction proteins with synthetic peptides. Biophys J 1994, 67, 1816-1822, doi:10.1016/S0006-3495(94)80663-0.

130. Jiang, J.; Hoagland, D.; Palatinus, J.A.; He, H.; lyyathurai, J.; Jourdan, L.J.; Bultynck, G.; Wang, Z.; Zhang, Z.; Schey, K.; et al. Interaction of $\alpha$ Carboxyl Terminus 1 Peptide With the Connexin 43 Carboxyl Terminus Preserves Left Ventricular Function After Ischemia-Reperfusion Injury. J Am Heart Assoc 2019, 8, e012385, doi:10.1161/JAHA.119.012385.

131. Evans, W.H.; Boitano, S. Connexin mimetic peptides: specific inhibitors of gap-junctional intercellular communication. Biochem.Soc.Trans. 2001, 29, 606-612.

132. Warner, A.; Clements, D.K.; Parikh, S.; Evans, W.H.; DeHaan, R.L. Specific motifs in the external loops of connexin proteins can determine gap junction formation between chick heart myocytes. J Physiol 1995, 488 ( Pt 3), 721-728, doi:10.1113/jphysiol.1995.sp021003.

133. Glass, B.J.; Hu, R.G.; Phillips, A.R.; Becker, D.L. The action of mimetic peptides on connexins protects fibroblasts from the negative effects of ischemia reperfusion. Biol Open 2015, 4, 1473-1480, doi:10.1242/bio.013573.

134. Desplantez, T.; Verma, V.; Leybaert, L.; Evans, W.H.; Weingart, R. Gap26, a connexin mimetic peptide, inhibits currents carried by connexin43 hemichannels and gap junction channels. Pharmacol Res 2012, 65, 546-552, doi:10.1016/j.phrs.2012.02.002. 
135. Davidson, J.O.; Green, C.R.; Nicholson, L.F.; O'Carroll, S.J.; Fraser, M.; Bennet, L.; Gunn, A.J. Connexin hemichannel blockade improves outcomes in a model of fetal ischemia. Ann Neuro/ 2012, 71, 121-132, doi:10.1002/ana.22654.

136. Wang, N.; De Bock, M.; Decrock, E.; Bol, M.; Gadicherla, A.; Bultynck, G.; Leybaert, L. Connexin targeting peptides as inhibitors of voltage- and intracellular Ca2+-triggered Cx43 hemichannel opening. Neuropharmacology 2013, 75, 506-516, doi:10.1016/j.neuropharm.2013.08.021.

137. Berman, R.S.; Martin, P.E.; Evans, W.H.; Griffith, T.M. Relative contributions of NO and gap junctional communication to endothelium-dependent relaxations of rabbit resistance arteries vary with vessel size. Microvasc Res 2002, 63, 115-128, doi:10.1006/mvre.2001.2352.

138. Elbadawy, H.M.; Mirabelli, P.; Xeroudaki, M.; Parekh, M.; Bertolin, M.; Breda, C.; Cagini, C.; Ponzin, D.; Lagali, N.; Ferrari, S. Effect of connexin 43 inhibition by the mimetic peptide Gap27 on corneal wound healing, inflammation and neovascularization. $\mathrm{Br}$ J Pharmaco/2016, 173, 2880-2893, doi:10.1111/bph.13568.

139. Wright, C.S.; Pollok, S.; Flint, D.J.; Brandner, J.M.; Martin, P.E. The connexin mimetic peptide Gap27 increases human dermal fibroblast migration in hyperglycemic and hyperinsulinemic conditions in vitro. J Cell Physiol 2012, 227, 77-87, doi:10.1002/jcp.22705.

140. Hawat, G.; Hélie, P.; Baroudi, G. Single intravenous low-dose injections of connexin 43 mimetic peptides protect ischemic heart in vivo against myocardial infarction. Journal of molecular and cellular cardiology 2012, 53, 559-566, doi:10.1016/j.yjmcc.2012.07.008.

141. Sorensen, C.M.; Salomonsson, M.; Braunstein, T.H.; Nielsen, M.S.; Holstein-Rathlou, N.H. Connexin mimetic peptides fail to inhibit vascular conducted calcium responses in renal arterioles. Am J Physiol Regul Integr Comp Physio/2008, 295, R840847, doi:10.1152/ajpregu.00491.2007.

142. Cotter, M.L.; Boitano, S.; Lampe, P.D.; Solan, J.L.; Vagner, J.; Ek-Vitorin, J.F.; Burt, J.M. The lipidated connexin mimetic peptide SRPTEKT- Hdc is a potent inhibitor of Cx43 channels with specificity for the pS368 phospho-isoform. Am J Physio/ Cell Physiol 2019, 317, C825-C842, doi:10.1152/ajpcell.00160.2019.

143. Matchkov, V.V.; Rahman, A.; Bakker, L.M.; Griffith, T.M.; Nilsson, H.; Aalkjaer, C. Analysis of effects of connexin-mimetic peptides in rat mesenteric small arteries. Am J Physiol Heart Circ Physiol 2006, 291, H357-367, doi:10.1152/ajpheart.00681.2005.

144. Solan, J.L.; Lampe, P.D. Connexin phosphorylation as a regulatory event linked to gap junction channel assembly. Biochim Biophys Acta 2005, 1711, 154-163, doi:10.1016/j.bbamem.2004.09.013.

145. Solan, J.L.; Lampe, P.D. Connexin43 phosphorylation: structural changes and biological effects. Biochem J 2009, 419, 261272, doi:BJ20082319 [pii] 10.1042/BJ20082319.

146. Simon, A.; Magyar, C.; Heja, L.; Kardon, J. Peptide binding sites of connexin proteins. Chemistry 2020, 2, 662-673, doi:10.3390/chemistry2030042.

147. Neijssen, J.; Herberts, C.; Drijfhout, J.W.; Reits, E.; Janssen, L.; Neefjes, J. Cross-presentation by intercellular peptide transfer through gap junctions. Nature 2005, 434, 83-88, doi:10.1038/nature03290.

148. Morley, G.E.; Taffet, S.M.; Delmar, M. Intramolecular interactions mediate pH regulation of connexin43 channels. Biophysical journal 1996, 70, 1294-1302, doi:10.1016/S0006-3495(96)79686-8.

149. Liu, S.; Taffet, S.; Stoner, L.; Delmar, M.; Vallano, M.L.; Jalife, J. A structural basis for the unequal sensitivity of the major cardiac and liver gap junctions to intracellular acidification: the carboxyl tail length. Biophysical journal 1993, 64, 1422-1433, doi:10.1016/S0006-3495(93)81508-X.

150. Moreno, A.P.; Chanson, M.; Elenes, S.; Anumonwo, J.; Scerri, I.; Gu, H.; Taffet, S.M.; Delmar, M. Role of the carboxyl terminal of connexin43 in transjunctional fast voltage gating. Circ Res 2002, 90,450-457, doi:10.1161/hh0402.105667.

151. Anumonwo, J.M.; Taffet, S.M.; Gu, H.; Chanson, M.; Moreno, A.P.; Delmar, M. The carboxyl terminal domain regulates the unitary conductance and voltage dependence of connexin40 gap junction channels. Circ Res 2001, 88, 666-673. 
152. D'hondt, C.; lyyathurai, J.; Wang, N.; Gourdie, R.G.; Himpens, B.; Leybaert, L.; Bultynck, G. Negatively charged residues (Asp378 and Asp379) in the last ten amino acids of the C-terminal tail of Cx43 hemichannels are essential for loop/tail interactions. Biochem Biophys Res Commun 2013, 432, 707-712, doi:10.1016/j.bbrc.2013.01.066.

153. Delmar, M.; Coombs, W.; Sorgen, P.; Duffy, H.S.; Taffet, S.M. Structural bases for the chemical regulation of Connexin43 channels. Cardiovasc Res 2004, 62, 268-275, doi:10.1016/j.cardiores.2003.12.030

\section{S0008636304000069 [pii].}

154. Gump, J.M.; Dowdy, S.F. TAT transduction: the molecular mechanism and therapeutic prospects. Trends Mol Med 2007, 13, 443-448, doi:10.1016/j.molmed.2007.08.002.

155. Lindgren, M.; Hällbrink, M.; Prochiantz, A.; Langel, U. Cell-penetrating peptides. Trends in pharmacological sciences 2000, 21 , 99-103, doi:10.1016/s0165-6147(00)01447-4.

156. Carrigan, C.N.; Imperiali, B. The engineering of membrane-permeable peptides. Anal Biochem 2005, 341, 290-298, doi:10.1016/j.ab.2005.03.026.

157. Yu, H.; Cao, X.; Li, W.; Liu, P.; Zhao, Y.; Song, L.; Chen, J.; Chen, B.; Yu, W.; Xu, Y. Targeting connexin 43 provides antiinflammatory effects after intracerebral hemorrhage injury by regulating YAP signaling. J Neuroinflammation 2020, 17, 322, doi:10.1186/s12974-020-01978-z.

158. De Smet, M.A.; Lissoni, A.; Nezlobinsky, T.; Wang, N.; Dries, E.; Pérez-Hernández, M.; Lin, X.; Amoni, M.; Vervliet, T.; Witschas, K.; et al. Cx43 hemichannel microdomain signaling at the intercalated disc enhances cardiac excitability. J Clin Invest 2021, 131, doi:10.1172/JCl137752.

159. Deschenes, S.M.; Walcott, J.L.; Wexler, T.L.; Scherer, S.S.; Fischbeck, K.H. Altered trafficking of mutant connexin32. J Neurosci $1997,17,9077-9084$.

160. Ressot, C.; Gomes, D.; Dautigny, A.; Pham-Dinh, D.; Bruzzone, R. Connexin32 mutations associated with X-linked CharcotMarie-Tooth disease show two distinct behaviors: loss of function and altered gating properties. J Neurosci 1998, 18, 40634075 .

161. Leithe, E.; Mesnil, M.; Aasen, T. The connexin 43 C-terminus: A tail of many tales. Biochim Biophys Acta Biomembr2018, 1860, 48-64, doi:10.1016/j.bbamem.2017.05.008.

162. Rhett, J.M.; Jourdan, J.; Gourdie, R.G. Connexin 43 connexon to gap junction transition is regulated by zonula occludens-1. Mol Biol Cel/ 2011, 22, 1516-1528, doi:10.1091/mbc.E10-06-0548.

163. Grek, C.L.; Prasad, G.M.; Viswanathan, V.; Armstrong, D.G.; Gourdie, R.G.; Ghatnekar, G.S. Topical administration of a connexin43-based peptide augments healing of chronic neuropathic diabetic foot ulcers: A multicenter, randomized trial. Wound Repair Regen 2015, 23, 203-212, doi:10.1111/wrr.12275.

164. Mugisho, O.O.; Green, C.R.; Zhang, J.; Acosta, M.L.; Rupenthal, I.D. Connexin43 hemichannels: A potential drug target for the treatment of diabetic retinopathy. Drug Discov Today 2019, 24, 1627-1636, doi:10.1016/j.drudis.2019.01.011.

165. Ghatnekar, G.S.; Grek, C.L.; Armstrong, D.G.; Desai, S.C.; Gourdie, R.G. The effect of a connexin43-based Peptide on the healing of chronic venous leg ulcers: a multicenter, randomized trial. J Invest Dermato/2015, 135, 289-298, doi:10.1038/jid.2014.318.

166. Grek, C.L.; Rhett, J.M.; Bruce, J.S.; Abt, M.A.; Ghatnekar, G.S.; Yeh, E.S. Targeting connexin 43 with alpha-connexin carboxylterminal (ACT1) peptide enhances the activity of the targeted inhibitors, tamoxifen and lapatinib, in breast cancer: clinical implication for ACT1. BMC Cancer 2015, 15, 296, doi:10.1186/s12885-015-1229-6.

167. Montgomery, J.; Richardson, W.J.; Marsh, S.; Rhett, J.M.; Bustos, F.; Degen, K.; Ghatnekar, G.S.; Grek, C.L.; Jourdan, L.J.; Holmes, J.W.; et al. The connexin 43 carboxyl terminal mimetic peptide alphaCT1 prompts differentiation of a collagen scar matrix in humans resembling unwounded skin. FASEB J 2021, 35, e21762, doi:10.1096/fj.202001881R.

168. Strauss, R.E.; Mezache, L.; Veeraraghavan, R.; Gourdie, R.G. The Cx43 carboxyl-terminal mimetic peptide $\alpha \mathrm{CT} 1$ protects endothelial barrier function in a ZO1 binding-competent manner. Biomolecules 2021, 11. 
169. Rhett, J.M.; Yeh, E.S. The Potential for Connexin Hemichannels to Drive Breast Cancer Progression through Regulation of the Inflammatory Response. Int J Mol Sci 2018, 19, doi:10.3390/ijms19041043.

170. Soder, B.L.; Propst, J.T.; Brooks, T.M.; Goodwin, R.L.; Friedman, H.I.; Yost, M.J.; Gourdie, R.G. The connexin43 carboxyl-terminal peptide ACT1 modulates the biological response to silicone implants. Plast Reconstr Surg 2009, 123, 1440-1451, doi:10.1097/PRS.0b013e3181a0741d.

171. Roskoski, R., Jr. Src protein-tyrosine kinase structure and regulation. Biochem Biophys Res Commun 2004, 324, 1155-1164, doi:10.1016/j.bbrc.2004.09.171.

172. Gangoso, E.; Thirant, C.; Chneiweiss, H.; Medina, J.M.; Tabernero, A. A cell-penetrating peptide based on the interaction between c-Src and connexin43 reverses glioma stem cell phenotype. Cell Death Dis 2014, 5, e1023, doi:10.1038/cddis.2013.560.

173. Pelaz, S.G.; Jaraiz-Rodriguez, M.; Alvarez-Vazquez, A.; Talaveron, R.; Garcia-Vicente, L.; Flores-Hernandez, R.; Gomez de Cedron, M.; Tabernero, M.; Ramirez de Molina, A.; Lillo, C.; et al. Targeting metabolic plasticity in glioma stem cells in vitro and in vivo through specific inhibition of C-Src by TAT-Cx43266-283. EBioMedicine 2020, 62, 103134, doi:10.1016/j.ebiom.2020.103134.

174. Han, X.; Zhang, W.; Yang, X.; Wheeler, C.G.; Langford, C.P.; Wu, L.; Filippova, N.; Friedman, G.K.; Ding, Q.; Fathallah-Shaykh, H.M.; et al. The role of Src family kinases in growth and migration of glioma stem cells. Int J Onco/ 2014, 45, 302-310, doi:10.3892/ijo.2014.2432.

175. Singh, S.; Trevino, J.; Bora-Singhal, N.; Coppola, D.; Haura, E.; Altiok, S.; Chellappan, S.P. EGFR/Src/Akt signaling modulates Sox2 expression and self-renewal of stem-like side-population cells in non-small cell lung cancer. Mo/ Cancer 2012, 11, 73, doi:10.1186/1476-4598-11-73.

176. Gangoso, E.; Talaverón, R.; Jaraíz-Rodríguez, M.; Domínguez-Prieto, M.; Ezan, P.; Koulakoff, A.; Medina, J.M.; Giaume, C.; Tabernero, A. A c-Src Inhibitor Peptide Based on Connexin43 Exerts Neuroprotective Effects through the Inhibition of Glial Hemichannel Activity. Front Mol Neurosci 2017, 10, 418, doi:10.3389/fnmol.2017.00418.

177. Bifunctional Cx43 Mimic Peptide Grafted Hyaluronic Acid Hydrogels Inhibited Tumor Recurrence and Stimulated Wound Healing for Postsurgical Tumor Treatment - He - 2020 - Advanced Functional Materials - Wiley Online Library. 2021, doi:10.1002/adfm.202004709.

178. Lamouille, S.; Smyth, J.W.; O'Rourke, L.; Kanabur, P.; Guo, S.; Jourdan, J.; Sheng, Z.; Gourdie, R.G. Abstract 4765: Targeting glioblastoma cancer stem cells with a novel Connexin43 mimetic peptide. 2017, doi:10.1158/1538-7445.AM2017-4765.

179. Sheng, Z. Connexin 43 peptidic medicine for glioblastoma stem cells. EBioMedicine 2021, 64, 103205, doi:10.1016/j.ebiom.2020.103205.

180. Grosely, R.; Kopanic, J.L.; Nabors, S.; Kieken, F.; Spagnol, G.; Al-Mugotir, M.; Zach, S.; Sorgen, P.L. Effects of phosphorylation on the structure and backbone dynamics of the intrinsically disordered connexin43 C-terminal domain. J Bio/ Chem 2013, 288, 24857-24870, doi:10.1074/jbc.M113.454389.

181. Solan, J.L.; Lampe, P.D. Specific Cx43 phosphorylation events regulate gap junction turnover in vivo. FEBS Lett 2014, 588, 1423-1429, doi:10.1016/j.febslet.2014.01.049.

182. Liao, C.K.; Cheng, H.H.; Wang, S.D.; Yeih, D.F.; Wang, S.M. PKC $\varepsilon$ mediates serine phosphorylation of connexin43 induced by lysophosphatidylcholine in neonatal rat cardiomyocytes. Toxicology 2013, 314, 11-21, doi:10.1016/j.tox.2013.08.001.

183. Solan, J.L.; Lampe, P.D. Kinase programs spatiotemporally regulate gap junction assembly and disassembly: Effects on wound repair. Semin Cell Dev Bio/2016, 50, 40-48, doi:10.1016/j.semcdb.2015.12.010.

184. Acosta, M.L.; Mat Nor, M.N.; Guo, C.X.; Mugisho, O.O.; Coutinho, F.P.; Rupenthal, I.D.; Green, C.R. Connexin therapeutics: blocking connexin hemichannel pores is distinct from blocking pannexin channels or gap junctions. Neural Regen Res 2021, 16, 482-488, doi:10.4103/1673-5374.290097. 
185. Willebrords, J.; Maes, M.; Crespo Yanguas, S.; Vinken, M. Inhibitors of connexin and pannexin channels as potential therapeutics. Pharmacol Ther 2017, 180, 144-160, doi:10.1016/j.pharmthera.2017.07.001.

186. Billaud, M.; Lohman, A.W.; Straub, A.C.; Looft-Wilson, R.; Johnstone, S.R.; Araj, C.A.; Best, A.K.; Chekeni, F.B.; Ravichandran, K.S.; Penuela, S.; et al. Pannexin1 Regulates alpha 1-Adrenergic Receptor-Mediated Vasoconstriction. Circulation Research 2011, 109, 80-U284, doi:10.1161/CIRCRESAHA.110.237594.

187. Billaud, M.; Chiu, Y.H.; Lohman, A.W.; Parpaite, T.; Butcher, J.T.; Mutchler, S.M.; DeLalio, L.J.; Artamonov, M.V.; Sandilos, J.K.; Best, A.K.; et al. A molecular signature in the pannexin1 intracellular loop confers channel activation by the alpha1 adrenoreceptor in smooth muscle cells. Sci Signa/2015, 8, ra17, doi:10.1126/scisignal.2005824.

188. Weilinger, N.L.; Tang, P.L.; Thompson, R.J. Anoxia-induced NMDA receptor activation opens pannexin channels via Src family kinases. J Neurosci 2012, 32, 12579-12588, doi:10.1523/JNEUROSCI.1267-12.2012.

189. Weilinger, N.L.; Lohman, A.W.; Rakai, B.D.; Ma, E.M.; Bialecki, J.; Maslieieva, V.; Rilea, T.; Bandet, M.V.; Ikuta, N.T.; Scott, L.; et al. Metabotropic NMDA receptor signaling couples Src family kinases to pannexin-1 during excitotoxicity. Nat Neurosci2016, doi:10.1038/nn.4236.

190. Diezmos, E.F.; Markus, I.; Perera, D.S.; Gan, S.; Zhang, L.; Sandow, S.L.; Bertrand, P.P.; Liu, L. Blockade of Pannexin-1 Channels and Purinergic P2X7 Receptors Shows Protective Effects Against Cytokines-Induced Colitis of Human Colonic Mucosa. Front Pharmaco/2018, 9, 865, doi:10.3389/fphar.2018.00865.

191. Shoji, K.F.; Sáez, P.J.; Harcha, P.A.; Aguila, H.L.; Sáez, J.C. Pannexin1 channels act downstream of P2X 7 receptors in ATPinduced murine T-cell death. Channels (Austin) 2014, 8, 142-156, doi:10.4161/chan.28122.

192. Garré, J.M.; Yang, G.; Bukauskas, F.F.; Bennett, M.V. FGF-1 Triggers Pannexin-1 Hemichannel Opening in Spinal Astrocytes of Rodents and Promotes Inflammatory Responses in Acute Spinal Cord Slices. J Neurosci 2016, 36, 4785-4801, doi:10.1523/JNEUROSCI.4195-15.2016.

193. Huang, G.Y.; Xie, L.J.; Linask, K.L.; Zhang, C.; Zhao, X.Q.; Yang, Y.; Zhou, G.M.; Wu, Y.J.; Marquez-Rosado, L.; McElhinney, D.B.; et al. Evaluating the role of connexin43 in congenital heart disease: Screening for mutations in patients with outflow tract anomalies and the analysis of knock-in mouse models. J Cardiovasc Dis Res 2011, 2, 206-212, doi:10.4103/0975-3583.89804.

194. Salameh, A.; Blanke, K.; Daehnert, I. Role of connexins in human congenital heart disease: the chicken and egg problem. Front Pharmaco/2013, 4, 70, doi:10.3389/fphar.2013.00070.

195. Delmar, M.; Makita, N. Cardiac connexins, mutations and arrhythmias. Curr Opin Cardiol 2012, 27, 236-241, doi:10.1097/HCO.0b013e328352220e.

196. Boengler, K.; Schulz, R. Connexin 43 and Mitochondria in Cardiovascular Health and Disease. Adv Exp Med Bio/2017, 982, 227-246, doi:10.1007/978-3-319-55330-6_12.

197. Srinivas, M.; Verselis, V.K.; White, T.W. Human diseases associated with connexin mutations. Biochim Biophys Acta Biomembr 2018, 1860, 192-201, doi:10.1016/j.bbamem.2017.04.024.

198. Fetoni, A.R.; Zorzi, V.; Paciello, F.; Ziraldo, G.; Peres, C.; Raspa, M.; Scavizzi, F.; Salvatore, A.M.; Crispino, G.; Tognola, G.; et al. Cx26 partial loss causes accelerated presbycusis by redox imbalance and dysregulation of Nfr2 pathway. Redox Bio/ 2018, 19, 301-317, doi:10.1016/j.redox.2018.08.002.

199. Beach, R.; Abitbol, J.M.; Allman, B.L.; Esseltine, J.L.; Shao, Q.; Laird, D.W. GJB2 Mutations Linked to Hearing Loss Exhibit Differential Trafficking and Functional Defects as Revealed in Cochlear-Relevant Cells. Front Cell Dev Biol 2020, 8, 215, doi:10.3389/fcell.2020.00215.

200. Shuja, Z.; Li, L.; Gupta, S.; Mese, G.; White, T.W. Connexin26 Mutations Causing Palmoplantar Keratoderma and Deafness Interact with Connexin43, Modifying Gap Junction and Hemichannel Properties. J Invest Dermato/ 2016, 136, 225-235, doi:10.1038/JID.2015.389. 
201. Maestrini, E.; Korge, B.P.; Ocana-Sierra, J.; Calzolari, E.; Cambiaghi, S.; Scudder, P.M.; Hovnanian, A.; Monaco, A.P.; Munro, C.S. A missense mutation in connexin26, D66H, causes mutilating keratoderma with sensorineural deafness (Vohwinkel's syndrome) in three unrelated families. Hum Mol Genet 1999, 8, 1237-1243, doi:10.1093/hmg/8.7.1237.

202. Yang, S.H.; Clemett, C.A.; Brimble, M.A.; O'Carroll, S.J.; Harris, P.W.R. Synthesis and biological evaluation of S-lipidated lipopeptides of a connexin 43 channel inhibitory peptide RSC Med Chem 2020, 11, 1041-1047, doi:10.1039/d0md00172d.

203. Marsh, S.R.; Pridham, K.J.; Jourdan, J.; Gourdie, R.G. Novel Protocols for Scalable Production of High Quality Purified Small Extracellular Vesicles from Bovine Milk. Nanotheranostics 2021, 5, 488-498, doi:10.7150/ntno.62213. 